Foss. Rec., 18, 81-104, 2015

www.foss-rec.net/18/81/2015/

Fossil Record

museum für

naturkunde

doi:10.5194/fr-18-81-2015

(C) Author(s) 2015. CC Attribution 3.0 License.

Open Access berlin

(c) (P)

\title{
Late Viséan (late Mississippian) ammonoids from the Barnett Shale, Sierra Diablo Escarpment, Culberson County, Texas, USA
}

\author{
A. L. Titus ${ }^{1}$, D. Korn ${ }^{2}$, J. E. Harrell ${ }^{3}$, and L. L. Lambert ${ }^{4}$ \\ ${ }^{1}$ Grand Staircase-Escalante National Monument, 669 S. Highway 89A, Kanab, UT 84741, USA \\ ${ }^{2}$ Museum für Naturkunde, Leibniz Institute for Evolution and Biodiversity Science, Invalidenstraße 43, \\ 10115 Berlin, Germany \\ ${ }^{3}$ Noble Energy Inc., Houston, TX 77070, USA \\ ${ }^{4}$ Department of Geological Sciences, The University of Texas at San Antonio, One UTSA Circle, San Antonio, \\ TX 78249, USA
}

Correspondence to: A. L. Titus (atitus@blm.gov)

Received: 3 February 2015 - Revised: 7 April 2015 - Accepted: 22 April 2015 - Published: 4 June 2015

\begin{abstract}
Mid-Carboniferous strata of the Barnett Shale in the Sierra Diablo region are deep water, offshore sediments deposited in the Marathon Foreland Basin. These strata contain a remarkably complete ammonoid record spanning from the Late Viséan to the middle Atokan (Moscovian). Late Viséan strata are referred to as the "Folks Member" of the Barnett Shale and locally yield numerous ammonoids. Three assemblages can be recognized, which contain, from oldest to youngest, Goniatites eganensis and Girtyoceras hamiltonense (Goniatites eganensis Zone), Goniatites multiliratus and Girtyoceras meslerianum (Goniatites multiliratus Zone), and Choctawites cumminsi and Pachylyroceras cloudi (Choctawites cumminsi Zone). We erect the new genera Choctawites and Uralyroceras to accommodate, respectively, the North American species "Goniatites choctawensis Shumard, 1863", "G. kentuckiensis Miller, 1889 " and "G. cumminsi Hyatt, 1893", and Uralian species formerly attributed to Pachylyroceras. For the material of "Pachylyroceras cloudi" of the South Urals, the new species name Uralyroceras arquatum is proposed.
\end{abstract}

ZooBank: http://zoobank.org/References/6C6A1411F88F-45C2-BA4A-D97C4CD4B415

\section{Introduction}

Late Viséan (Goniatites and Neoglyphioceras genus zones sensu Ramsbottom and Saunders, 1985) ammonoids are widespread in foreland basin settings around the margin of the North American continent and have been described or illustrated from the Chainman Shale of Nevada and Utah (Miller et al., 1949, 1952; Gordon, 1965, 1971; Furnish and Saunders, 1971; Titus and Riley, 1997), the Barnett Shale of central Texas (Smith, 1903; Plummer and Scott, 1937; Miller and Youngquist, 1948; Miller and Downs, 1950; Plummer, 1950; Elias, 1956; Gordon, 1960, 1965), the Caney Shale of Oklahoma (Girty, 1909; Miller and Furnish, 1940a; Gordon, 1962, 1965; Branson, 1964; McCaleb et al., 1964; Saunders et al., 1977; Korn et al., 2004), the Moorefield Formation of Arkansas (Girty, 1911; Gordon, 1965; Saunders et al., 1977), the Pride Mountain Shale of Alabama (Drahovzal, 2009), the Newman Limestone and equivalent formations of Kentucky (Miller and Faber, 1892; Miller and Gurley, 1896; Smith, 1903; Miller and Furnish, 1940a; McCaleb et al., 1964; Gordon, 1965; Furnish and Saunders, 1971; Titus and Riley, 1997; Work and Mason, 2009b), and the Ste. Genevieve Limestone of Illinois and Indiana (Smith, 1903; Collinson, 1955).

Although mentioned repeatedly in the literature and tabulated in a 50-year-old faunal list (King, 1965), the Late Viséan ammonoids of the Barnett Shale (Helms Formation of most older papers) in west Texas have never been previously described. Intrigued by this repeated mention in the 


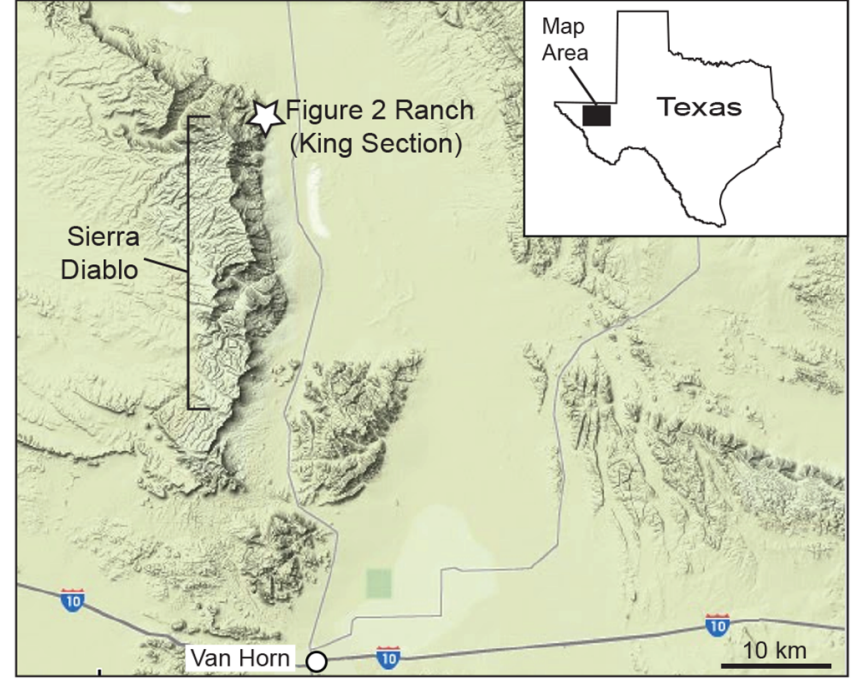

Figure 1. Reference map showing location of the Figure 2 Ranch King section, Sierra Diablo, Culberson County, Texas.

literature of abundant late Mississippian ammonoids in the Sierra Diablo and the total lack of detailed description of the fauna, in 2000 A. L. Titus twice visited the Figure 2 Ranch (then owned by the very gracious Mr Ron Stasny) where the only significant Mississippian ammonoid bearing strata crop out (Fig. 1). It quickly became obvious that the Figure 2 Ranch section preserves one of the most important ammonoid-bearing late Mississippian to early Pennsylvanian sections in North America, and possibly the world. Subsequently to A. L. Titus' work on the Figure 2 Ranch, L. L. Lambert initiated field studies on the Figure 2 Mississippian section with J. E. Harrell in 2003 and 2004, measuring sections and making extensive collections of both Mississippian and Pennsylvanian ammonoids.

Unfortunately, since the Figure 2 Ranch was sold in 2005, researchers have no longer had access. Harrell (2007) presented an overview of the ammonoids they had recovered as part of the stratigraphic revision they were recommending for the Carboniferous of the region. This paper describes for the first time the complete Late Viséan ammonoid succession of the Barnett Shale at the Figure 2 Ranch, needed now more than ever since there will be no access to this locality in the foreseeable future.

\section{Previous work}

Although Pennsylvanian (Atokan) ammonoids have been extensively described and figured from the Sierra Diablo (Plummer and Scott, 1937; Miller and Furnish, 1940b, 1958), no systematic analysis of Viséan ammonoids from this region has ever been published. Prior to this work, only two Viséan specimens had been figured from the area; a "Girtyoceras meslerianum" (referred to by us as G. hamiltonense) by McCaleb et al. (1964, pl. 2, figs. 8, 9) and a specimen of Pachylyroceras cloudi in Furnish and Saunders (1971, pl. 2, fig. 5). The next year, King (1965) listed eight Viséan species from the Barnett Shale; "Goniatites crenistria Phillips", "Goniatites choctawensis Shumard", "Goniatites sp.", "Girtyoceras sp. cf. G. meslerianum (Girty)", "Neoglyphioceras cloudi (Miller and Youngquist)", "Neoglyphioceras sp.", and "Lyrogoniatites sp. cf. L. newsomi (Smith)" based on collections made by J. B. Knight, A. K. Miller, and W. M. Furnish in the 1930s and 1940s. We have not examined the collections that the faunal list was based upon, but it is clear they are stratigraphically mixed; "Goniatites crenistria" and "Girtyoceras sp. cf. G. meslerianum" are from our lowest recognized ammonoid zone (Goniatites eganensis Biozone) and the remainder of material from our newly established Choctawites cumminsi Zone. Because King's collections were actually tied to a published measured section, we consider this the only other significant report of Viséan ammonoids from the Sierra Diablo region. In contrast, there are several mentions that Mississippian ammonoids occur in the Sierra Diablo within faunal descriptions of material from other localities (Miller and Furnish, 1940a; Miller and Youngquist, 1948; Youngquist, 1949).

\section{Stratigraphy of the Sierra Diablo (A. L. Titus, J. E. Harrell, L. L. Lambert)}

\subsection{Geological overview}

The Carboniferous stratigraphy of the Sierra Diablo was recently summarized by Harrell (2007). Virtually every major stratigraphic unit from the Viséan to the Bashkirian has yielded ammonoids in this region (Harrell, 2007), with the Viséan to late Serpukhovian section being particularly fossiliferous and rich in ammonoids. All of the Viséan material in this report came from the "Folks Member" of the Mississippian-Pennsylvanian Barnett Shale, which is exposed in only three places in the northeast portion of the Sierra Diablo below an imposing escarpment formed out of the Permian Hueco Formation (King, 1965), entirely within the Figure 2 Ranch property. Although generally homoclinal and south-dipping, the Folks Member is locally faulted, folded, and intruded by small dikes and sills which caused local contact metamorphism. The entire pre-Permian section was folded, faulted, and eroded into a peneplain during the Ouachita Orogeny before being covered by the sediments of the Permian Paw Paw Formation, which along with the Hueco Formation is the source for most of the erosional debris that covers the non-resistant Folks Member.

The Folks Member is comprised mostly of mudstone and siltstone, with prominent carbonate concretions, phosphatic pebble-rich lags, and thin-bedded pelagic micritic limestone that all point towards a largely sediment-starved depositional regime during the Late Viséan and early Serpukhovian (Ti- 

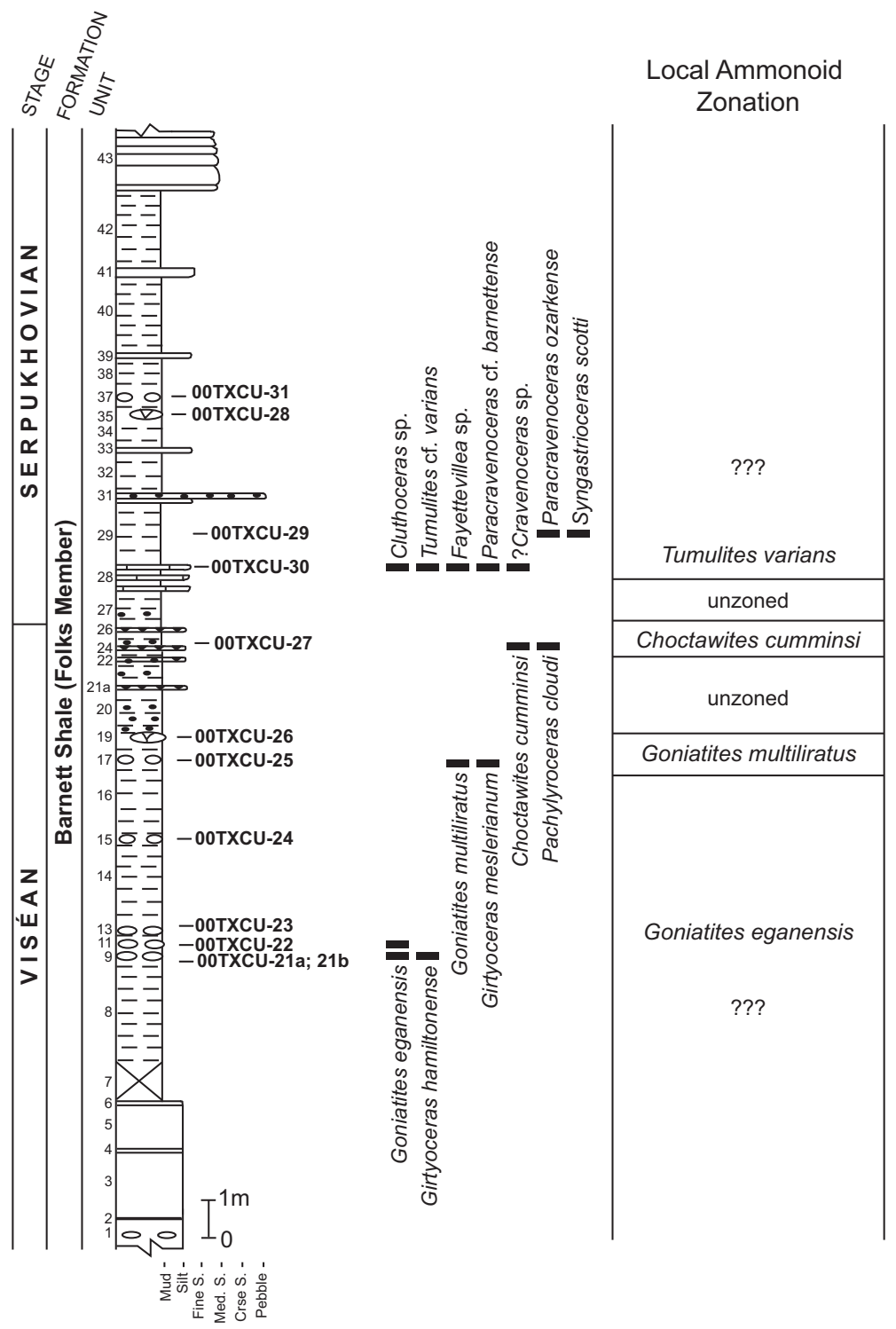

Figure 2. Columnar King's section on the Figure 2 Ranch, Sierra Diablo, Texas, with the position of fossil samples and proposed biostratigraphic attribution.

tus, 1999). This character is generally similar to that of timeequivalent strata of the Barnett Shale exposed in the Llano Uplift, which is even more condensed than the Sierra Diablo section. The Folks Member is abundantly fossiliferous and yields a largely pelagic fauna, but also a dwarf, low diversity benthic assemblage of gastropods and bivalves in the phosphate pebble lag horizons. Well-preserved, uncrushed ammonoids occur through much of the unit, preserved either as testiferous moulds in carbonate concretions or beds, or as phosphatic steinkerns in the pebble lag rich shales. Although there are three sections now known to yield Viséan ammonoids in the northern Sierra Diablo (Harrell, 2007) only one of these, herein referred to as King's section, had been studied and sampled extensively enough to allow for detailed analysis when all access to the Figure 2 Ranch to researchers was ended. Fortunately the other two sections do not appear to preserve any fauna or significant horizons not seen at King's section.

\subsection{King's section}

Our King's section (Fig. 2) is the same as Section 11 published by King (1965) and from which all of the Mississippian ammonoids in his Barnett Shale faunal list came from. The beds at King's section dip northeast about $15^{\circ}$. Exposures through most of the approximate $46 \mathrm{~m}$ of Barnett Shale section here are excellent.

The start of our measured section is near the slope break, in a drainage located at UTM coordinates (NAD27): 13R 
0512497E; $3482258 \mathrm{~N}\left(31.47504^{\circ} \mathrm{N}, 104.86844^{\circ} \mathrm{W}\right)$. The covered interval just below our bed 1 has scattered pieces of large ex situ ammonoid-bearing concretions. These concretion fragments were derived from our beds 9,11 , and 13. The only ammonoids we collected from these loose pieces were specimens of Goniatites eganensis Korn and Titus, 2011. The lowest $7 \mathrm{~m}$ of exposed section did not yield in situ threedimensional ammonoids, only rare leiorhynchid and lingulid brachiopods and Nereites-type trace fossils.

Seven metres above the base of the section are three separate horizons of 1-1.5 m diameter concretions less than a half metre apart from each other stratigraphically. The lowest of these three concretionary horizons (bed 9) yielded an abundant ammonoid fauna dominated by the crenistriate species G. eganensis, but also containing Girtyoceras hamiltonense Korn and Titus, 2011 (samples 00TXCU-21a and 00TXCU$21 \mathrm{~b}$ ). The next concretion horizon (bed 11) yielded uncommon specimens of G. eganensis (sample 00TXUT-22), while the highest concretionary horizon (bed 13) in this immediate grouping did not yield any diagnostic material.

Approximately $2 \mathrm{~m}$ higher is another single band of elliptical $0.3 \mathrm{~m}$ diameter concretions (bed 15) that we obtained no diagnostic specimens from. Above the bed 15 concretions is $2.5 \mathrm{~m}$ of non-concretionary shale/siltstone, which ends at beds $17-19$, two closely spaced concretionary horizons separated by $40 \mathrm{~cm}$ of siltstone. The concretions of bed 17 yielded an assemblage of Goniatites multiliratus Gordon, 1962 and Girtyoceras meslerianum (Girty, 1909) (sample 00TXCU25 ). Although we cannot make out the suture lines on the Goniatites specimens from this horizon, we are confident of its assignment because its ornament is highly diagnostic given other biostratigraphic constraints on the sample, which include the co-occurring Girtyoceras. The upper concretionary horizon (bed 19), which is highly septarian, did not yield diagnostic material.

The next $4 \mathrm{~m}$ of section is a highly condensed, fossiliferous succession of glauconitic nodular phosphatic mudstone punctuated by a thin oxidized silty/sandy bed (bed 21a) and three limonitic iron bands (beds 22, 24, 26). The phosphatic intervals are sediment-starved hardgrounds, some of which exhibit extensive recycling. Phosphatic-glauconitic steinkerns of Choctawites cumminsi (Hyatt, 1893) and Pachylyroceras cloudi (Miller and Youngquist, 1948) are common (sample 00TXCU-27), and occur with an impoverished benthic molluscan fauna that was not collected. The highest iron band hardground (bed 26) is overlain by $1.3 \mathrm{~m}$ of phosphatic shale, which yielded no fossils.

Three thin, nodular packstone beds (collectively bed 28) only centimetres apart yielded, along with the bivalve Caneyella wapanuckensis Girty, 1909, the following ammonoid taxa: Beyrichoceratoides sp., Tumulites $\mathrm{cf}$. T. varians McCaleb et al., 1964, Fayettevillea sp., Paracravenoceras cf. P. barnettense (Plummer and Scott, 1937) and ?Cravenoceras $\mathrm{sp}$. Large, but partially crushed limonite pseudomorph steinkerns of Paracravenoceras ozarkense Gordon, 1960 and
Syngastrioceras scotti (Miller and Youngquist, 1948) (sample 00TXCU-29) occur in the $1.6 \mathrm{~m}$ of shale above bed 28 . Capping the $1.6 \mathrm{~m}$ thick shale interval is a prominent thin yellow siltstone (bed 30) that is very similar to bed 21. Bed 30 is immediately overlain a $0.3 \mathrm{~m}$ thick bed (bed 31 ) that contains phosphate clasts up to $3 \mathrm{~cm}$ in diameter.

Two metres higher is a couplet of concretionary horizons bearing striate goniatitids that look virtually identical to beds 17 and 19, but in reverse stratigraphic order, with the septarian horizon (bed 35) being the lower of the two. Although it was not detected in 2000 when the section was measured, the ammonoid evidence, coupled with the repetition of the distinctive yellow siltstone horizon and concretionary beds, seems to suggest there is a small-scale structural repetition of this portion of the section.

The highest ammonoids recovered from King's section are from bed 37 , which probably due to structural repetition, contains the same assemblage found in bed 17. Because we did not observe an obvious structural break in the exposed section, there is a small chance that beds 35-37 are in correct stratigraphic position and therefore Serpukhovian in age. If this is the case, then the lirate goniatitids probably belong to Lusitanoceras, which are known from lower Serpukhovian strata of the Antler and Marathon-Ouachita foreland basin systems (e.g. Drahovzal and Quinn, 1972). Unfortunately, without sutural evidence we cannot assign specimens from bed 37 to a genus with certainty and our bias, given the lithologic repetition and lack of associated cravenoceratids or glaphyritids, is the structural hypothesis. Beds 43-45 are not seen in any of the other Sierra Diablo sections and the remaining $22 \mathrm{~m}$ of section up to the angular unconformity with the overlying Paw Paw Formation is clearly from shallower water facies. Aside from some sparse crinozoan debris, this upper interval lacks obvious macrofossils.

\subsection{Biostratigraphic interpretation}

Late Viséan. - The ammonoids Goniatites eganensis and Girtyoceras hamiltonense were discovered from the base of the measured section, as well as other localities to the south, indicating that the Goniatites eganensis Biozone, which was first delineated in the Chainman Shale of Utah and Nevada (Korn and Titus, 2011), is the lowest in the Sierra Diablo Barnett section that can be diagnosed with in situ material (Fig. 2). Specimens of Goniatites multiliratus from bed 17 indicate that the zone for that species can also be diagnosed in that general part of the section. This same general succession can be observed entirely, or in part, in the Chainman Shale of Nevada and Utah, the Caney Shale of Oklahoma, and Moorefield Formation of Arkansas (Korn and Titus, 2011).

The highest Viséan assemblages of the Sierra Diablo (from beds 23-25) contain Choctawites cumminsi and Pachylyroceras cloudi. Previously, the entire post-Goniatites multiliratus interval has been lumped into a single "Goniatites gra- 

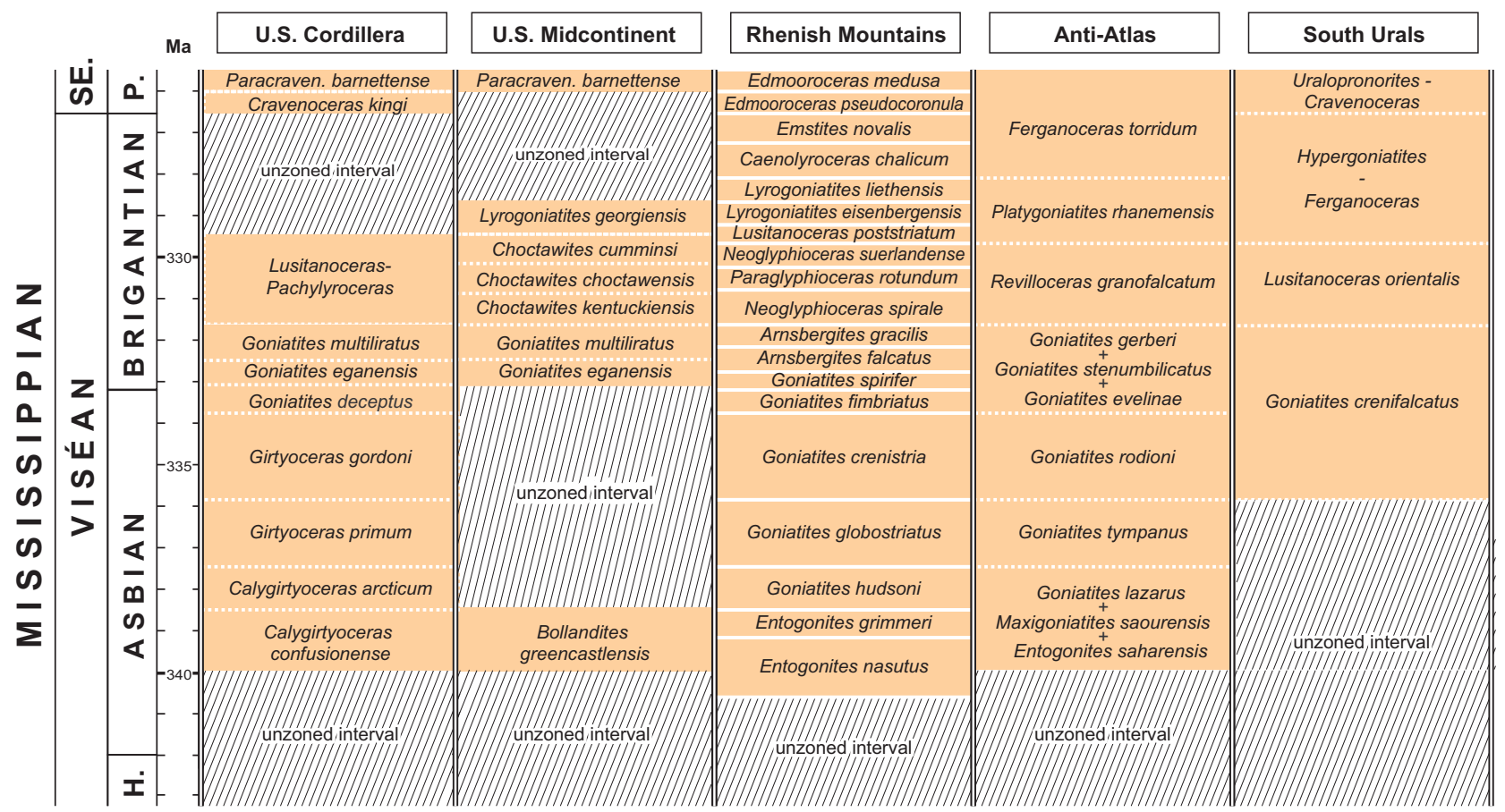

Figure 3. Global correlation chart for upper Viséan and lowest Serpukhovian ammonoid zones; after Ruzhencev and Bogoslovskaya (1971), Korn and Horn (1996), Korn et al. (2007), Korn and Kaufmann (2009) and Korn and Titus (2011).

nosus" (now referred to as Lusitanoceras Pereira de Sousa, 1923) Biozone (Gordon, 1965; Saunders et al., 1977; Webster et al., 1984). It is now clear to us that both the taxonomy and biostratigraphy of this interval in North America is much more complicated and can be subdivided in the eastern USA using species of the characteristic genus Choctawites. As Ch. cumminsi is particularly common in Texas, we use it to name a new ammonoid biozone, whose reference locality is the Chappel Hill section of the Barnett Shale, San Saba, Texas. It is defined as the interval between the first occurrence of the nominate taxon and the first appearance of Cravenoceras. Associated ammonoids in Texas include Sulcogirtyoceras ornatissimum, Pachylyroceras sp., Lusitanites sp., and various dimorphoceratids. At present, no unequivocal younger Late Viséan ammonoid zones can be defined in North America (Fig. 3), although the position of Lyrogoniatites georgiensis would presumably fall into this interval.

Although not discernible in the Sierra Diablo section, we also erect the Choctawites kentuckiensis Biozone with the Buffalo Wallow reference section (Moorefield Shale; east of Batesville, Arkansas; Malinky and Mapes, 1982) for the interval between the first appearance of that taxon and the appearance of Choctawites choctawensis. Key North American first occurrences of ammonoids in this zone include Sulcogirtyoceras (as S. limatum), Lusitanoceras, Neoglyphioceras, Lusitanites, and Ruddellites (Gordon, 1965; Malinky and Mapes, 1982). The interval between the $C h$. kentuckiensis and Ch. cumminsi biozones contains Choctaw- ites choctawensis, Neoglyphioceras caneyanum, Lusitanites sp., Sulcogirtyoceras cf. S. ornatissimum, and dimorphoceratids. Based on this assemblage, we establish the Choctawites choctawensis Biozone with Girty's station 2078 as the reference section (Caney Shale; Pittsburg County, Oklahoma; Branson et al., 1959), defined as the interval between that taxon's first appearance (Fig. 3) and the appearance of Choctawites cumminsi.

Serpukhovian. - Although not the focus of this paper, Serpukhovian ammonoids are abundant in the Sierra Diablo sections and it is clear that a succession of multiple zones could be recognized at least as high as the Reticuloceras Genus zone (Harrell, 2007). Earliest Serpukhovian ammonoids are discussed here to give the Late Viséan succession a better context. However, no high-resolution zonation for lower Serpukhovian ammonoids equivalent to the Pendleian Stage of the British Isles currently exists for North America and establishing one is beyond the scope of this work. The oldest Serpukhovian ammonoids collected from the Sierra Diablo (Tumulites, Paracravenoceras, Fayettevillea, Beyrichoceratoides, Eosyngastrioceras) are from beds 28-29 and are almost identical to those found in the middle and upper Fayetteville Shale of northern Arkansas. Collectively, they are diagnosed as the "Tumulites varians-Cravenoceras fayettevillae" zone of Saunders et al. (1977), probably equivalent to the British $E_{1} b$. As might be expected in a deeper-water offshore section, earliest Serpukhovian assemblages (equaling British $E_{1}$ a) characterized elsewhere in North America by 
a distinctive Girtyoceras-Cravenoceras sensu stricto assemblage are not preserved as three-dimensional material in the Sierra Diablo area.

\subsection{Global correlations}

High-resolution global correlations for the Late Viséan (Asbian and Brigantian in the British subdivision scheme) ammonoids of North America were proposed by Korn and Titus (2011). Our work on the Sierra Diablo sections has not substantively changed this earlier interpretation and no further discussion on correlation of pre-Choctawites kentuckiensis Biozone assemblages is warranted.

Choctawites cumminsi Biozone - Because the genus Choctawites is endemic to North America, direct correlations are difficult. However, Sulcogirtyoceras associated with Choctawites cumminsi at San Saba (S. ornatissimum), Texas, and Choctawites choctawensis (S. cf. S. ornatissimum) in the Caney Shale of Oklahoma are very similar to the Rhenish Mountain species $S$. burhennei, which co-occurs with Paraglyphioceras rotundum. In both Europe and North America, the earliest occurrence of Neoglyphioceras is in the immediately underlying assemblage. We think the similar pattern of occurrence for these two distinctive morphotypes forms a better basis for correlation than the species or genus ranges of various goniatitid taxa such as Lusitanoceras and Dombarites, which appear to occur diachronously in various basins. As a result, we equate the occurrence of NeOglyphioceras in the Choctawites kentuckiensis assemblage of the Moorefield Formation with the Neoglyphioceras spirale zone of western Europe (Fig. 3). The overlying Choctawites choctawensis and Choctawites cumminsi zones thus correlate with the Paraglyphioceras rotundum and Neoglyphioceras suerlandense-Lusitanoceras postriatum intervals of the Rhenish Mountains sections (Fig. 3). We believe this correlation is the most parsimonious solution as it synchronizes the first appearance of S. burhennei-type Sulcogirtyoceras, Neoglyphioceras, and advanced forms of more openly umbilicate neoglyphioceratids like $N$. suerlandense (very similar to the more evolute North American genus Pachylyroceras). Unfortunately Choctawites is very rare in the US cordilleran region. Specimens tentatively referable to $\mathrm{Ch}$. cumminsi are known from the Chainman Shale in west Utah, occurring in the upper portion of the range of Lusitanoceras, associated with Lusitanoceras, Lusitanites, Sulcogirtyoceras ornatissimum, and Pachylyroceras utahense.

\section{Systematic descriptions (D. Korn, A. L. Titus)}

Descriptive terminology for conch morphology is patterned after Korn (2010). Abbreviations of conch dimensions (Fig. 4) are conch diameter (dm), whorl width (ww), whorl height (wh), umbilical width ( $\left.\mathrm{uw}=\mathrm{dm}_{1}-\mathrm{wh}_{1}-\mathrm{wh}_{2}\right)$ and aperture height (ah). The whorl expansion rate (WER) is cal-

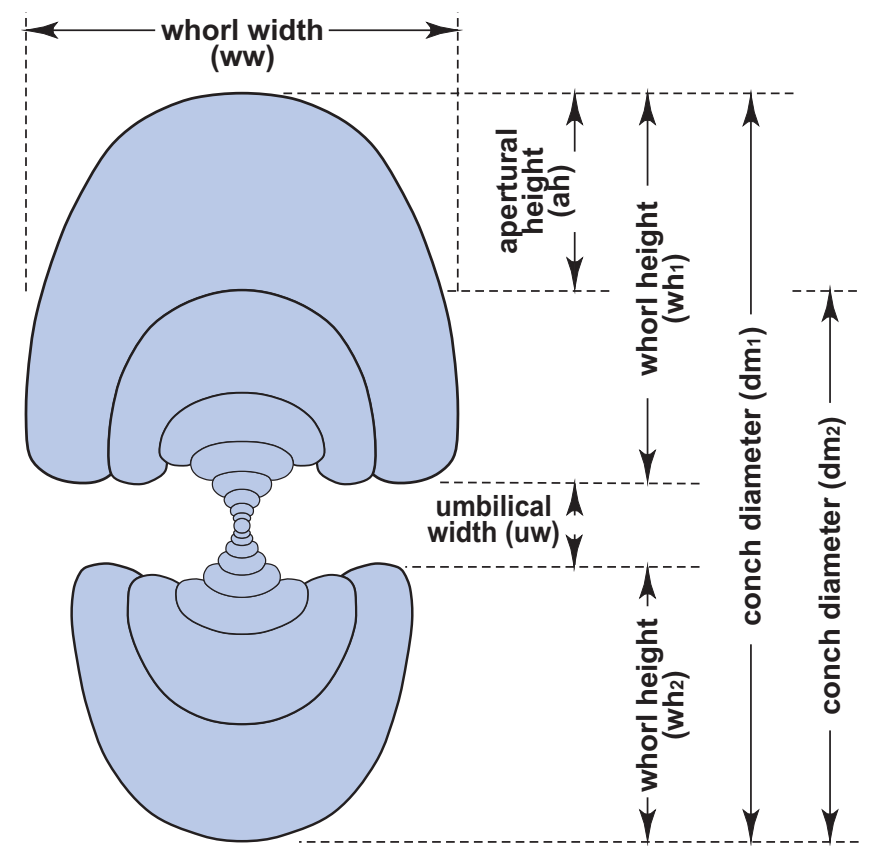

Figure 4. Descriptive terms for the conch morphology and suture lines of the ammonoids described here.

culated using the algorithm of Korn and Klug (2007): WER $=[\mathrm{dm} /(\mathrm{dm}-\mathrm{ah})]^{2}$ or $\left(\mathrm{dm}_{1} / \mathrm{dm}_{2}\right)^{2}$. The imprint zone rate (IZR) characterizes the whorl overlap, and it can be calculated by IZR $=(w h-a h) / w h$. The terminology of the suture lines is taken from Korn et al. (2003).

The material described in the following account is held in the following collections with abbreviations as follows:

NPL - Non-vertebrate Paleontology Lab, The University of Texas in Austin

MB.C. - Cephalopod collection in the Museum für Naturkunde Berlin

USNM - U.S. National Museum, Washington, D.C.

SUI - State University of Iowa, Iowa City

Order Goniatitida Hyatt, 1884

Suborder Goniatitina Hyatt, 1884

Superfamily Girtyocerataceae Wedekind, 1918

Family Girtyoceratidae Wedekind, 1918

Family diagnosis: Girtyocerataceae with ontogenetically changing conch shape; inner whorls evolute, umbilicus closing during ontogeny, adult stage often discoidal and oxyconic. Ornament with biconvex growth lines. Suture line with V-shaped external lobe and rounded ventrolateral saddle; adventive lobe $\mathrm{V}$-shaped with slightly sinuous flanks.

Remark: For the genus composition of the family and a discussion of the characteristics and limits, see Korn and Titus (2011). 
Table 1. Conch dimensions (in millimetres) and proportions for Girtyoceras hamiltonense Korn and Titus, 2011, from the Sierra Diablo.

\begin{tabular}{lrrrrrrrrr}
\hline Specimen & dm & ww & wh & uw & ah & ww / dm & ww / wh & uw / dm & WER \\
\hline NPL 68361 & 21.9 & 9.1 & 10.9 & 4.0 & 7.0 & 0.42 & 0.83 & 0.18 & 1.94 \\
same & 17.3 & 8.4 & 8.5 & 3.6 & - & 0.49 & 0.99 & 0.21 & - \\
NPL 68362 & 14.8 & 6.7 & 6.9 & 3.7 & - & 0.45 & 0.97 & 0.25 & - \\
UTSA 07062 & 10.7 & 5.3 & 4.3 & 3.0 & - & 0.50 & 1.23 & 0.28 & - \\
\hline
\end{tabular}

\section{Girtyoceras Wedekind, 1918}

Type species: Adelphoceras meslerianum Girty, 1909 (original designation).

Genus diagnosis: Girtyoceratidae with moderately large conch that during ontogeny passes through very different morphological stages: early juveniles are widely umbilicate with crescent-shaped whorl cross section, later thickly discoidal or pachyconic with subangular or rounded umbilical margin. The intermediate stage has rounded flanks and venter and the adult stage is lenticular and oxyconic. Without or with very faint ventrolateral grooves. Suture line with Vshaped external lobe, moderately high median saddle, narrowly rounded ventrolateral saddle, and V-shaped adventive lobe.

Remark: For the species composition of the genus and a discussion of the characteristics and limits, see Korn and Titus (2011).

\section{Girtyoceras hamiltonense Korn and Titus, 2011 (Fig. 5)}

1949 Girtyoceras aff. G. meslerianum. - Miller et al., p. 608, pl. 99, figs. 9, 10.

1964 Girtyoceras meslerianum. - McCaleb et al., p. 13 (part), pl. 2, figs. 8, 9.

2011 Girtyoceras hamiltonense Korn and Titus, p. 150, text-figs. 30, 31 [for more synonymy].

Holotype: Specimen UMNH IP 3127; illustrated by Korn and Titus (2011, fig. 30B).

Type locality and horizon: Hamilton Canyon, bed 44; Camp Canyon Member of Chainman Formation, Goniatites eganensis Biozone.

Material: Four specimens, NPL 68361 (sample OOTXCU21q), NPL 68362 (sample OOTXCU-21b), NPL 68363 (sample OOTXCU-21a), UTSA 07062.

Diagnosis: For a complete diagnosis see Korn and Titus (2011).

Description: The largest specimen, nearly $22 \mathrm{~mm}$ conch diameter (Table 1), is almost fully ornamented and has a thinly discoidal, subinvolute conch shape $(\mathrm{ww} / \mathrm{dm}=0.42$; $\mathrm{uw} / \mathrm{dm}=0.18$ ). At the largest diameter, it possesses an angular umbilical margin, subparallel flanks, and a narrowly rounded venter. The fine growth lines are strongly biconvex with a prominent ventrolateral projection and a deep ventral sinus. The last volution displays four shell constrictions
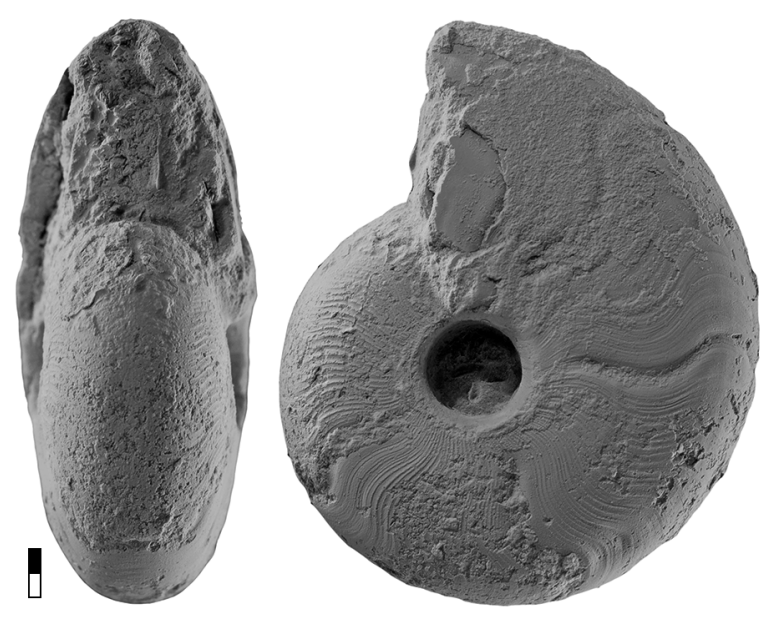

Figure 5. Girtyoceras hamiltonense Korn and Titus, 2011 from the Figure 2 Ranch section, Sierra Diablo. Specimen NPL 68361 from bed 9 (sample 00TXCU-21b); × 2.5.

extending parallel to the growth lines. They originate just outside the umbilical margin on the inner flank area; they are deepest on the mid-flank but continue across the venter (Fig. 5).

The next smaller specimen (NPL 68362) has a conch diameter of nearly $15 \mathrm{~mm}$ with similar conch proportions ( $\mathrm{ww} / \mathrm{dm}=0.45 ; \mathrm{uw} / \mathrm{dm}=0.25$ ). It is a partly testiferous internal mould with predepositional breakage to the living chamber. There are four constrictions, which are, as in all specimens, visible externally. The fine rib density is about 12 per millimetre.

The smallest specimen (UTSA 07062) is approximately $10 \mathrm{~mm}$ in diameter, thickly discoidal, and broken obliquely, but nearly in half, with the other half missing. The umbilical shoulders are angular and about $90^{\circ}$. The umbilical width index is entirely within a narrow range. Ribs and constrictions are moderately sinuous, and just start to develop a ventral sinus at about $8 \mathrm{~mm}$ diameter. There are three constrictions.

Discussion: G. hamiltonense is the stratigraphically oldest Girtyoceras species currently known from the Sierra Diablo section. It resembles G. gordoni Korn and Titus, 2011, G. welleri Gordon, 1965, and G. meslerianum (Girty, 1909). However, G. gordoni has less sinuous ribs and constrictions at comparable diameters, while $G$. welleri has a slightly narrower umbilicus between 6 and $20 \mathrm{~mm}$ conch diameter and 


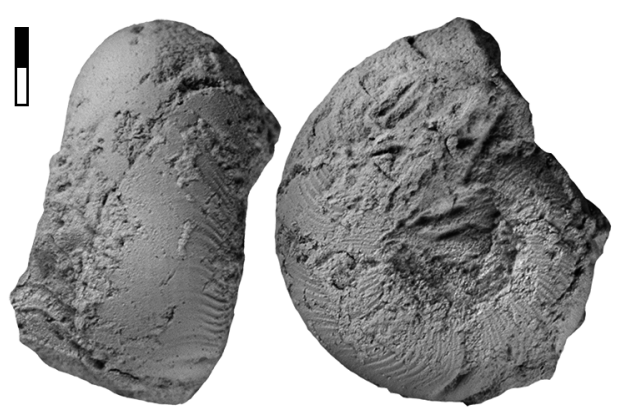

Figure 6. Girtyoceras meslerianum (Girty, 1909) from the Figure 2 Ranch section, Sierra Diablo. Specimen NPL 68364 from bed 17 (sample 00TXCU-25); × 4.0.

a more narrowly rounded ventral profile at diameters between 6 and $15 \mathrm{~mm}$. G. hamiltonense is now known from Nevada and Utah (Chainman Shale) and the Sierra Diablo (bed 9). The near time-equivalent species $G$. welleri occurs in the lower portion of Moorefield Formation near Batesville, Arkansas, and the Caney Shale of the Arbuckle Mountains region. In every case, these eastern occurrences are the oldest known horizons with a Goniatites assemblage at their respective localities.

\section{Girtyoceras meslerianum (Girty, 1909) (Figs. 6 and 7)}

1909 Adelphoceras meslerianum. - Girty, p. 66, pl. 12, figs. $1-3 \mathrm{c}$.

1918 Girtyoceras meslerianum. - Wedekind, p. 140.

1964 Girtyoceras meslerianum. - McCaleb et al., p. 13 (part), pl. 1, figs. 4-6.

1965 Girtyoceras meslerianum. - Gordon (part), pl. 24, Figs. 17-22, 30-32, text-figs. 63A, B, 64D.

Holotype: Specimen USNM 119594; illustrated by Girty (1909, pl. 12, figs. 1-1c).

Type locality and horizon: USGS locality 2083 , Sec. 14, T. 2 S., R. 7 E., northwest of Wapanucka, Johnston County, Oklahoma; Delaware Creek Member of Caney Shale, Goniatites multiliratus Biozone.

Material: Three immature specimens (NPL 68364 through NPL 68366) from bed 25 (sample 00TXCU-25).

Diagnosis: Species of Girtyoceras with a thickly discoidal, widely umbilicate conch at $6-8 \mathrm{~mm}$ diameter $(\mathrm{ww} / \mathrm{dm}=$ $0.50-0.60$; uw $/ \mathrm{dm}=0.45-0.55$ ), and a thinly discoidal, narrowly umbilicate conch at $20 \mathrm{~mm}$ diameter $(\mathrm{ww} / \mathrm{dm}=$ 0.45 ; uw $/ \mathrm{dm}=0.20)$. Whorl cross section strongly depressed in juveniles $(5 \mathrm{~mm}$ diameter) with rounded trapezoidal whorl cross section, followed by an intermediate stage with rounded venter and angular umbilical margin (above $7 \mathrm{~mm}$ diameter), and a discoidal stage (above $20 \mathrm{~mm}$ diameter) with acute venter. Ornament with sharp riblets in the juvenile stage; coarse prorsiradiate growth lines with concavoconvex course in the intermediate stage and fine biconvex growth lines in the adult stage. Strong shell constrictions in intermediate growth stages.

Description: The three specimens are all mostly testiferous. No sutures are visible. The specimen that represents the largest diameter (NPL 68366) is only a whorl fragment and poorly preserved. However, it represents a specimen that is clearly advanced over NPL 68364 (at least $12 \mathrm{~mm}$ in diameter) and shows the prominent tongue-shaped salient formed in the ribs and constrictions that are typical of this stage.

The better preserved of the two larger specimens (NPL 68364 ) is nearly $10 \mathrm{~mm}$ in diameter (Fig. 6). By $8 \mathrm{~mm}$ diameter the umbilical margin forms a strong right angle and the ribs and constrictions (which number four per whorl, are moderately deep and visible on both the internal moulds and external shell) are very strongly deflected anteriorly. The ribs and constrictions also form a distinct ventral sulcus at this stage. Faint longitudinal lines can be seen in the ventral area.

The smallest specimen (NPL 68365) is transitioning from the widely umbilicate acutely marginated form to the almost parallel-sided thickly discoidal form with a $90^{\circ}$ umbilical shoulder. The flanks and venter are gently rounded. Fine thread-like riblets originate from the umbilical margin and deflect anteriorly at the ventrolateral margin. The ribs are straight across the venter.

Discussion: Girtyoceras meslerianum is a rare taxon in the Sierra Diablo sections mostly because well-preserved threedimensional material is difficult to obtain from the concretions that bear its assemblage. Although interpreted rather broadly in the past, in our view, G. meslerianum is a morphological intermediate between $G$. hamiltonense and the stratigraphically younger taxon Sulcogirtyoceras limatum. It bears the more compressed conch form, strongly developed anterior deflection of the ribs and constrictions on the ventrolateral shoulder, and wider umbilicus of the latter (uw / dm $=0.31$ ), but has the weaker ornament and lack of ventrolateral sulcus of the former. Thus G. meslerianum might be confused with $G$. hamiltonense and small specimens (smaller than $12 \mathrm{~mm}$ ) of $S$. limatum. However, G. meslerianum can be readily differentiated from $G$. hamiltonense because the latter has a consistently narrower umbilicus (uw / $\mathrm{dm}=0.25$ at $16 \mathrm{~mm}$ diameter). Early members of the genus Sulcogirtyoceras develop a prominent ventrolateral sulcus at approximately $12-15 \mathrm{~mm}$ diameter, but also have slightly stronger ribs and constrictions at comparable stages (less than $20 \mathrm{~mm}$ diameter). Smaller specimens of more advanced species of Sulcogirtyoceras have more depressed whorls.

Species that are stratigraphically older than G. hamiltonense in North America have less sinuous constrictions and narrower umbilici at comparable diameters (e.g. G. gordoni), while younger Serpukhovian species (e.g. Girtyoceras jasperense Gordon) are more narrowly umbilicate and more robust (higher-value ww / wh ratios). Girtyoceras meslerianum appears to be limited to the Goniatites multiliratus Biozone in both the mid-continent USA and the western Cordillera (Chainman Shale). It is rather uncommon outside 
Table 2. Conch ontogeny of Girtyoceras meslerianum (Girty, 1909); based on material from Jackfork Creek, Oklahoma (Fig. 7).

\begin{tabular}{|c|c|c|c|}
\hline $\mathrm{dm}$ & Conch shape & Whorl cross section shape & Aperture \\
\hline $1.5 \mathrm{~mm}$ & $\begin{array}{l}\text { thickly discoidal; subevolute } \\
(\mathrm{ww} / \mathrm{dm}=0.45-0.60 ; \mathrm{uw} / \mathrm{dm}=0.40- \\
0.45)\end{array}$ & $\begin{array}{l}\text { moderately depressed; moderately embracing } \\
\text { (ww / wh } 1.80-2.00 ; \text { IZR }=0.20-0.25 \text { ) }\end{array}$ & $\begin{array}{l}\text { low } \\
(\mathrm{WER} \sim 1.65)\end{array}$ \\
\hline $5 \mathrm{~mm}$ & $\begin{array}{l}\text { thickly discoidal; evolute } \\
(\mathrm{ww} / \mathrm{dm}=0.55-0.50 ; \mathrm{uw} / \mathrm{dm}=0.50- \\
0.55)\end{array}$ & $\begin{array}{l}\text { strongly depressed; moderately embracing } \\
(\mathrm{ww} / \mathrm{wh}=2.25-2.50 ; \mathrm{IZR}=0.25-0.30)\end{array}$ & $\begin{array}{l}\text { low } \\
(\mathrm{WER}=1.50-1.60)\end{array}$ \\
\hline $10 \mathrm{~mm}$ & $\begin{array}{l}\text { thickly discoidal; subevolute } \\
(\mathrm{ww} / \mathrm{dm}=0.50 ; \mathrm{uw} / \mathrm{dm}=0.35)\end{array}$ & $\begin{array}{l}\text { weakly depressed; strongly embracing } \\
(\mathrm{ww} / \mathrm{wh}=1.25 ; \mathrm{IZR}=0.35-0.40)\end{array}$ & $\begin{array}{l}\text { moderate } \\
(\mathrm{WER}=1.75-1.90)\end{array}$ \\
\hline $20 \mathrm{~mm}$ & $\begin{array}{l}\text { thinly discoidal; subinvolute } \\
\text { (ww / dm } \sim 0.45 ; \text { uw / dm } \sim 0.20 \text { ) }\end{array}$ & $\begin{array}{l}\text { weakly compressed; strongly embracing } \\
\text { (ww / wh }=0.80 ; \text { IZR } \sim 0.40 \text { ) }\end{array}$ & $\begin{array}{l}\text { high } \\
(\text { WER } \sim 2.10)\end{array}$ \\
\hline
\end{tabular}

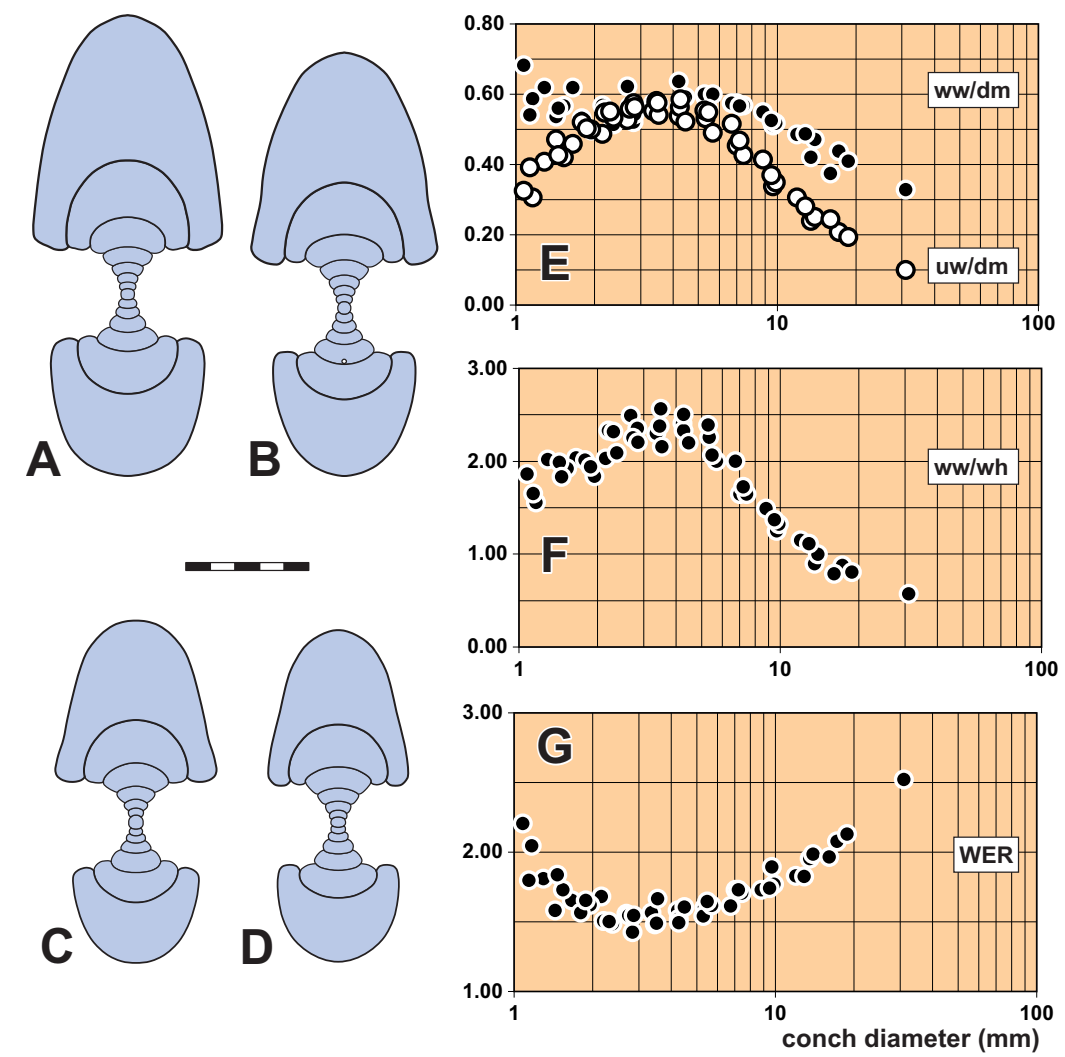

Figure 7. Girtyoceras meslerianum (Girty, 1909), conch cross sections and ontogenetic trajectories of material from the Caney Shale of Jackfork Creek near Ada, Oklahoma (a-d). (a) Specimen MB.C.25466; × 2.5. (b) Specimen MB.C.25467; × 2.5. (c) Specimen MB.C.25468; $\times 2.5$. (d) Specimen MB.C. $25469 ; \times 2.5$. $(\mathbf{e}-\mathbf{g})$, ontogenetic development of the conch width index $($ ww $/ \mathrm{dm})$, umbilical width index (uw / dm), and WER of the sectioned specimens and type material.

Table 3. Conch dimensions (in millimetres) and proportions for Girtyoceras meslerianum (Girty, 1909) from the type area and the Sierra Diablo.

\begin{tabular}{lrrrrrrrrrr}
\hline Specimen & $\mathrm{dm}$ & ww & wh & uw & ah & ww / dm & ww / wh & uw /dm & WER & IZR \\
\hline USNM 119594 (holotype) & 16.0 & 6.0 & 7.6 & 3.9 & 4.6 & 0.38 & 0.79 & 0.24 & 2.00 & 0.40 \\
NPL 68364 & 9.5 & 5.1 & 4.5 & 3.1 & 2.5 & 0.54 & 1.10 & 0.33 & 1.85 & 0.44 \\
NPL 68365 & 6.8 & 3.8 & 1.9 & 2.5 & - & 0.56 & 1.90 & 0.37 & - & - \\
\hline
\end{tabular}


Table 4. Conch dimensions (in millimetres) and proportions for reference specimens of Goniatites eganensis Korn and Titus, 2011 from the Sierra Diablo.

\begin{tabular}{lrrrrrrrrrr}
\hline Specimen & dm & ww & wh & uw & ah & ww / dm & ww / wh & uw / dm & WER & IZR \\
\hline NPL 68431 & 47.3 & 31.7 & 23.9 & 2.9 & 10.6 & 0.67 & 1.33 & 0.06 & 1.66 & 0.56 \\
NPL 68471 & 37.5 & 26.4 & 18.4 & 2.0 & 7.1 & 0.70 & 1.43 & 0.05 & 1.52 & 0.61 \\
NPL 68493 & 26.9 & 21.5 & 13.8 & 1.9 & 5.7 & 0.80 & 1.56 & 0.07 & 1.61 & 0.59 \\
NPL 68389 & 18.4 & 15.5 & 9.7 & 0.9 & 3.9 & 0.84 & 1.60 & 0.05 & 1.61 & 0.60 \\
\hline
\end{tabular}

of its type area, with the only other definitive occurrences we know of at San Saba, Texas in the base of the Barnett Formation and in the Chainman Shale at the classic Duckwater locality (not mentioned by Korn and Titus, 2011). It should occur in the Goniatites multiliratus Biozone of the upper Pool Creek Member of the Moorefield Formation, but specimens from this interval are all crushed (Gordon, 1965).

Superfamily Goniatitaceae de Haan, 1825

Family Goniatitidae de Haan, 1825

For the subfamily composition of the family and a discussion of the characteristics and limits, see Korn and Ebbighausen (2008) and Korn et al. (2010).

Subfamily Goniatitinae de Haan, 1825

For the genus composition of the subfamily and a discussion of the characteristics and limits, see Korn and Titus (2011).

\section{Goniatites de Haan, 1825}

Type species: Conchiliolithus Nautilites (sphaericus) Martin, 1809 [nomen nudum], equal to Ammonites sphaericus Sowerby, 1814 (Opinion 420 ICZN, 1956).

Diagnosis: Goniatitinae with subinvolute inner whorls; the umbilicus becomes closed in early ontogeny. External lobe usually V-shaped and rarely Y-shaped, very narrow or narrow, usually with slightly curved flanks.

For the species composition of the genus and a discussion of the characteristics and limits, see Korn and Titus (2011).

\section{Goniatites eganensis Korn and Titus, 2011 (Fig. 8)}

2011 Goniatites eganensis Korn and Titus, p. 175, text-figs. 51-54 [for more synonymy].

Holotype: Specimen UMNH IP 4021; illustrated by Korn and Titus (2011, fig. 51B).

Type locality and horizon: Trough Springs Canyon, bed 6 (sample 93NVLI-3); Camp Canyon Member of Chainman Formation, Goniatites eganensis Biozone.

Material: 127 specimens with conch diameters up to $48 \mathrm{~mm}$ from samples 00TXCU-20a-00TXCU-20f; 00TXCU-21a, and 00TXCU-21b.
Diagnosis: Goniatites with a globular conch between 2 and $8 \mathrm{~mm}$ diameter (ww / dm 0.85-0.90) and thickly pachyconic conch (ww/dm 0.75-0.80) at $20 \mathrm{~mm}$ diameter. Umbilicus moderate in early ontogeny (uw $/ \mathrm{dm}=0.20-0.30$ at $2 \mathrm{~mm}$ diameter) and very narrow in all stages larger than $4 \mathrm{~mm}$ diameter (uw / dm 0.02-0.10). Umbilical wall convexly rounded in all stages. Aperture low or moderately high (WER $=1.70-1.80$ at $20 \mathrm{~mm}$ diameter). Ornament with crenulated, slightly biconvex, and rectiradiate growth lines; external sinus shallow. Suture line at $25 \mathrm{~mm}$ conch diameter with narrow external lobe ( 0.55 of the external lobe depth; 1.25 of the ventrolateral saddle width), and moderately low median saddle ( 0.40 of the external lobe depth). External lobe V-shaped with narrow, V-shaped prongs; ventrolateral saddle subangular.

Description: Four specimens are selected to outline the morphology of the material from the Sierra Diablo. Unfortunately, inner whorls are largely recrystallized and thus do not contain solid information about the conch ontogeny.

Specimen NPL 68431 is a fully chambered specimen of $47 \mathrm{~mm}$ conch diameter; it is representative for a larger growth stage (Fig. 8a). The pachyconic conch (ww $/ \mathrm{dm}=0.67$; uw $/ \mathrm{dm}=0.06$ ) is very narrowly umbilicate and possesses a broadly rounded, wide venter and a steep umbilical wall. Parts of the specimen are covered with shell remains. These show fine and crenulated growth lines, which extend with weakly biconvex course across flanks and venter, forming equally high dorsolateral and ventrolateral projections and shallow lateral and ventral sinuses.

The smaller specimen NPL 68471 ( $38 \mathrm{~mm} \mathrm{dm}$ ) shows very similar conch proportions but differs in the slightly coarser, irregularly spaced growth lines (Fig. 8b). Specimens NPL $68493(27 \mathrm{~mm} \mathrm{dm})$ and NPL $68389(18.4 \mathrm{~mm} \mathrm{dm})$ are thickly pachyconic conchs with stronger depressed whorl cross section (Fig. 8c, d). The larger of the two possesses wellpreserved shell ornament with biconvex, strongly crenulated growth lines. These form a shallow lateral sinus and a very shallow ventral sinus. The smaller of the two possesses weakly crenulated growth lines standing in wide distances. 

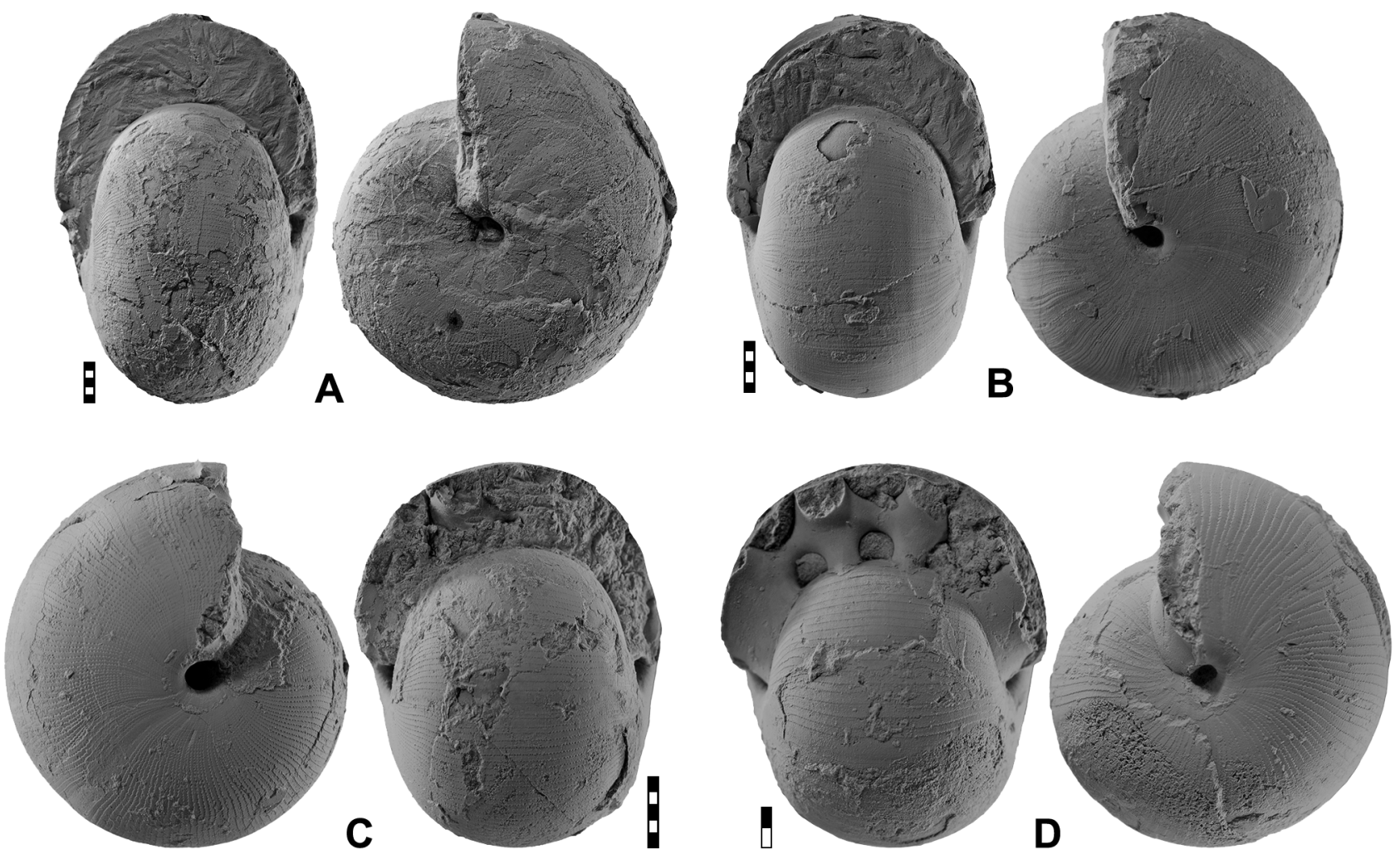

Figure 8. Goniatites eganensis Korn and Titus, 2011 from the Figure 2 Ranch section, Sierra Diablo. (a) Specimen NPL 68431 from bed 9 (sample OOTXCU-21b); × 1.0. (b) Specimen NPL 68471 from bed 9 (sample OOTXCU-21b); $\times 1.25$. (c) Specimen NPL 68493 from bed 11 (sample OOTXCU-22); × 1.75. (d) Specimen NPL 68389 from bed 9 (sample OOTXCU-21a); $\times 2.5$.

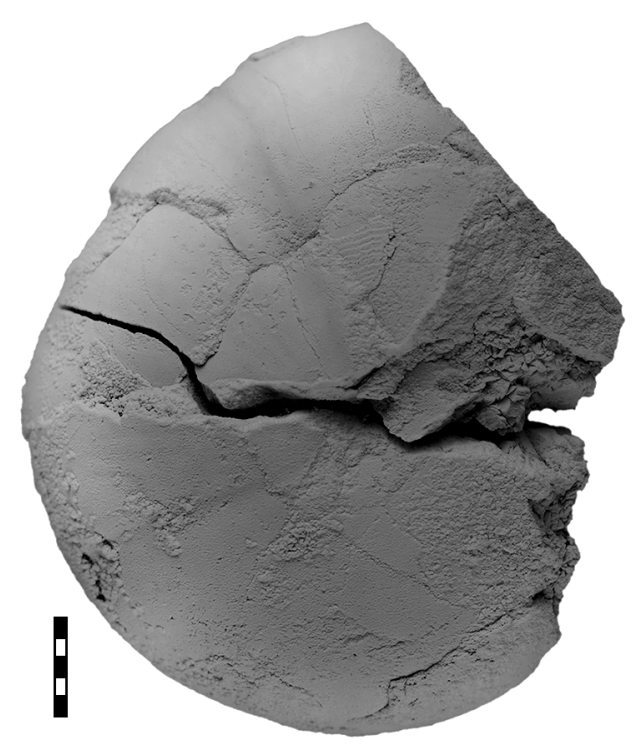

Figure 9. Goniatites multiliratus Gordon, 1962 from the Figure 2 Ranch section, Sierra Diablo. Specimen NPL 68494 from bed 17 (sample OOTXCU-25); × 2.0.

\section{Goniatites multiliratus Gordon, 1962 (Fig. 9)}

1909 Goniatites choctawensis. - Shumard, 1863; Girty, p. 59 (part), pl. 13, fig. 1.

1962 Goniatites multiliratus Gordon, p. 356, text-fig. 1A.

1964 Goniatites choctawensis. - Branson, figs. 1-2.

1965 Goniatites multiliratus. - Gordon, p. 186, pl. 18, figs. 8-12 [for more synonymy].

Holotype: Specimen USNM 119499; illustrated by Gordon (1965, pl. 18, figs. 9-12).

Type locality and horizon: USGS locality 6619A, $2 \mathrm{~km}$ south of Buckhorn (Murray County, Oklahoma); Caney Shale, Goniatites multiliratus Biozone.

Material: Three specimens (NPL 68494 through NPL 68496 from sample 00TXCU-25).

Diagnosis: Goniatites with a globular conch between 2 and $8 \mathrm{~mm}$ diameter (ww / dm 0.85-1.10) and thickly pachyconic to globular conch (ww / dm 0.80-0.85) at $20 \mathrm{~mm}$ diameter. Umbilicus moderately wide in early ontogeny (uw $/ \mathrm{dm}=$ $0.30-0.35$ at $2 \mathrm{~mm}$ diameter) and very narrow in all stages larger than $4 \mathrm{~mm}$ diameter (uw / dm 0.02-0.10). Umbilical wall convexly rounded in all stages. Aperture low or moderately high (WER $=1.60-1.80$ at $20 \mathrm{~mm}$ diameter). Ornament with more than 200 spiral lines and crenulated, slightly bi- 
Table 5. Character matrix of the genera within the subfamily Dombaritinae for the cladistic analysis presented here.

\begin{tabular}{|c|c|c|c|c|c|c|c|c|c|c|c|c|c|c|c|c|c|c|c|c|c|c|c|c|c|c|}
\hline & 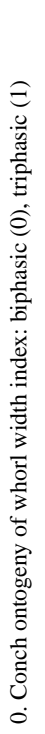 & 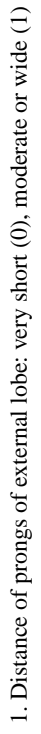 & 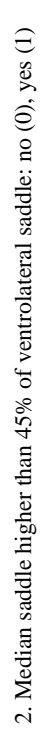 & 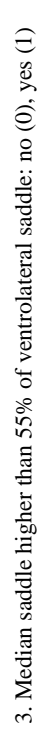 & 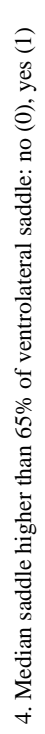 & 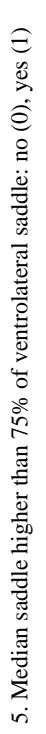 & 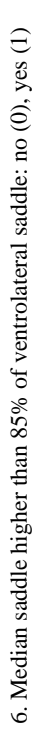 & 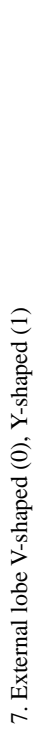 & 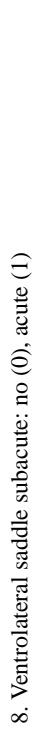 & 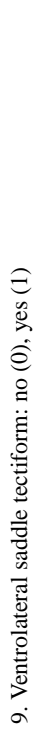 & 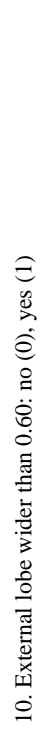 & 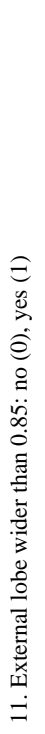 & 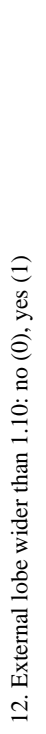 & 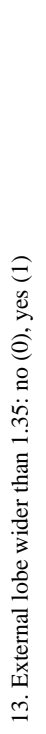 & 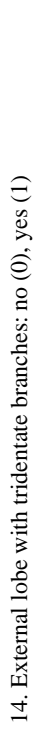 & 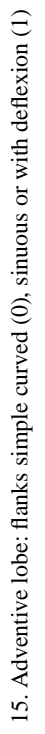 & 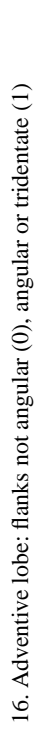 & 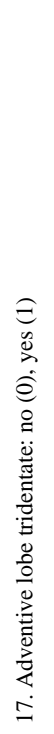 & 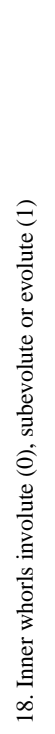 & 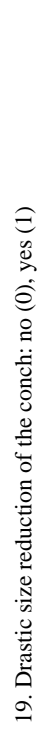 & 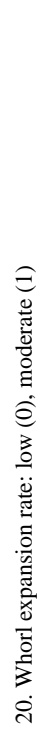 & 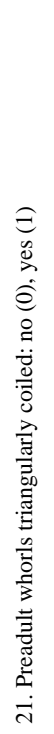 & 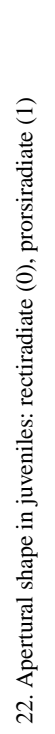 & 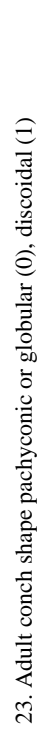 & 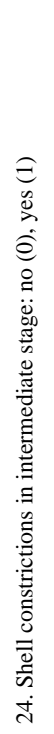 & 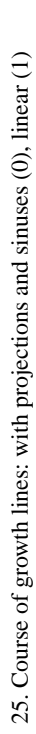 \\
\hline Progoniatites pilus & 0 & 0 & 0 & 0 & 0 & 0 & 0 & 0 & 0 & 0 & 0 & 0 & 0 & 0 & 0 & 0 & 0 & 0 & 0 & 0 & 0 & 0 & 0 & 0 & $?$ & 0 \\
\hline Goniatites crenistria & 1 & 1 & 0 & 0 & 0 & 0 & 0 & 0 & 1 & 0 & 0 & 0 & 0 & 0 & 0 & 0 & 0 & 0 & 0 & 0 & 0 & 0 & 0 & 0 & 0 & 0 \\
\hline Arnsbergites falcatus & 1 & 1 & 1 & 0 & 0 & 0 & 0 & 0 & 0 & 0 & 1 & 0 & 0 & 0 & 0 & 1 & 0 & 0 & 1 & 0 & 0 & 0 & 1 & 0 & 0 & 0 \\
\hline Hibernicoceras hibernicum & 1 & 1 & 1 & 0 & 0 & 0 & 0 & 0 & 0 & 0 & 1 & 0 & 0 & 0 & 0 & 1 & 0 & 0 & 1 & 0 & 0 & 0 & 1 & 0 & 0 & 0 \\
\hline Paraglyphioceras rotundum & 1 & 1 & 1 & 0 & 0 & 0 & 0 & 0 & 0 & 0 & 1 & 0 & 0 & 0 & 0 & 0 & 0 & 0 & 1 & 0 & 0 & 0 & 0 & 0 & 0 & 0 \\
\hline Lusitanoceras poststriatum & 1 & 1 & 1 & 0 & 0 & 0 & 0 & 1 & 0 & 1 & 1 & 0 & 0 & 0 & 0 & 1 & 0 & 0 & 1 & 0 & 0 & 1 & 1 & 0 & 1 & 0 \\
\hline Goniatitella agricola & $?$ & 1 & 0 & 0 & 0 & 0 & 0 & $?$ & 0 & 0 & 0 & 0 & 0 & 0 & 0 & 1 & 0 & 0 & 0 & 1 & 1 & 0 & 0 & 0 & 0 & 1 \\
\hline Neogoniatites milleri & 1 & 1 & 1 & 1 & 1 & 0 & 0 & 0 & 0 & 0 & 1 & 0 & 0 & 0 & 0 & 0 & 0 & 0 & 1 & 0 & 0 & 0 & 0 & 0 & 0 & 0 \\
\hline Hypergoniatites exiguus & 1 & 0 & 0 & 0 & 0 & 0 & 0 & 1 & 1 & 0 & 0 & 0 & 0 & 0 & 0 & 0 & 0 & 0 & 0 & 0 & 1 & 0 & 0 & 0 & 0 & 0 \\
\hline Dombarites tectus & 1 & 1 & 1 & 1 & 1 & 1 & 0 & 1 & 1 & 1 & 1 & 1 & 0 & 0 & 0 & 1 & 1 & 0 & 1 & 0 & 0 & 0 & 1 & 0 & 1 & 0 \\
\hline Proshumardites delepinei & 1 & 1 & 1 & 1 & 1 & 1 & 1 & 1 & 0 & 1 & 1 & 1 & 0 & 0 & 0 & 1 & 1 & 1 & 1 & 0 & 0 & 1 & 1 & 0 & 1 & 0 \\
\hline Platygoniatites molaris & 1 & 1 & 1 & 1 & 1 & 1 & 0 & 1 & 1 & 1 & 1 & 1 & 1 & 0 & 0 & 1 & 0 & 0 & 1 & 0 & 0 & 1 & 1 & 1 & 1 & 0 \\
\hline Delepinoceras bressoni & 1 & 1 & 1 & 1 & 1 & 1 & 1 & 1 & 0 & 1 & 1 & 1 & 1 & 1 & 1 & 1 & 0 & 0 & 1 & 0 & 0 & 1 & 1 & 1 & 1 & 0 \\
\hline Choctawites choctawensis & 1 & 1 & 1 & 1 & 0 & 0 & 0 & 1 & 0 & 1 & 1 & 0 & 0 & 0 & 0 & 1 & 1 & 0 & 1 & 0 & 0 & 0 & 1 & 0 & 0 & 0 \\
\hline Revilloceras granofalcatum & 1 & 1 & 1 & 1 & 0 & 0 & 0 & 1 & 1 & 1 & 1 & 0 & 0 & 0 & 0 & 1 & 0 & 0 & 1 & 0 & 0 & 1 & 1 & 0 & 1 & 0 \\
\hline Dombarites falcatoides & 1 & 1 & 1 & 1 & 1 & 0 & 0 & 1 & 1 & 1 & 1 & 0 & 0 & 0 & 0 & 1 & 0 & 0 & 1 & 0 & 0 & 1 & 1 & 0 & 1 & 0 \\
\hline
\end{tabular}

convex, and rectiradiate growth lines; external sinus shallow. Suture line at $25 \mathrm{~mm}$ conch diameter with narrow external lobe $(0.55$ of the external lobe depth; 1.00 of the ventrolateral saddle width), and moderately low median saddle $(0.45$ of the external lobe depth). External lobe Y-shaped with very narrow, V-shaped prongs; ventrolateral saddle subacute.

Description: The largest specimen (NPL 68494) has a partly crushed body chamber, but the phragmocone appears to be uncrushed (Fig. 9). The conch is, at $30 \mathrm{~mm}$ diameter, thinly pachyconic ( $\mathrm{ww} / \mathrm{dm}=0.70$ ) with a very narrow umbilicus. Shell fragments are visible at some places. They show fine spiral lines, which in accompany with crenulated growth lines form a spider web-like pattern. The steinkern is smooth except for wide, shallow constrictions.

The smallest specimen (NPL 68495) is partly crushed and has a diameter of $15 \mathrm{~mm}$. Faint traces of spiral ornament show that this feature has developed by this diameter. Like both of the other specimens, the phragmocone is extensively recrystallized. The medium sized specimen was difficult to extract and the only useful data that can be obtained is that it shows strong spiral lines, with a density of 13 per $2 \mathrm{~mm}$, at an estimated diameter of $25 \mathrm{~mm}$.

Discussion: This species can easily be confused with the stratigraphically older species $G$. deceptus, which occurs in Nevada and Utah sections of Chainman Shale. The main differences between the two species are the generally wider conch in G. multiliratus (ww / dm $=0.80-0.85$ at $20 \mathrm{~mm}$ diameter in $G$. multiliratus in contrast to $0.65-0.70$ in G. decep$t u s$ ) and the wider external lobe with higher median saddle in G. multiliratus.

G. multiliratus is the stratigraphically youngest species of Goniatites known from North America, and certain features of its conch ontogeny (prolonged subevolute juvenile stage) and suture line (relatively high median saddle and angular flanks of the adventive lobe) may foreshadow the evolution of a Choctawites-like form, although there would clearly be other intermediate stages. 


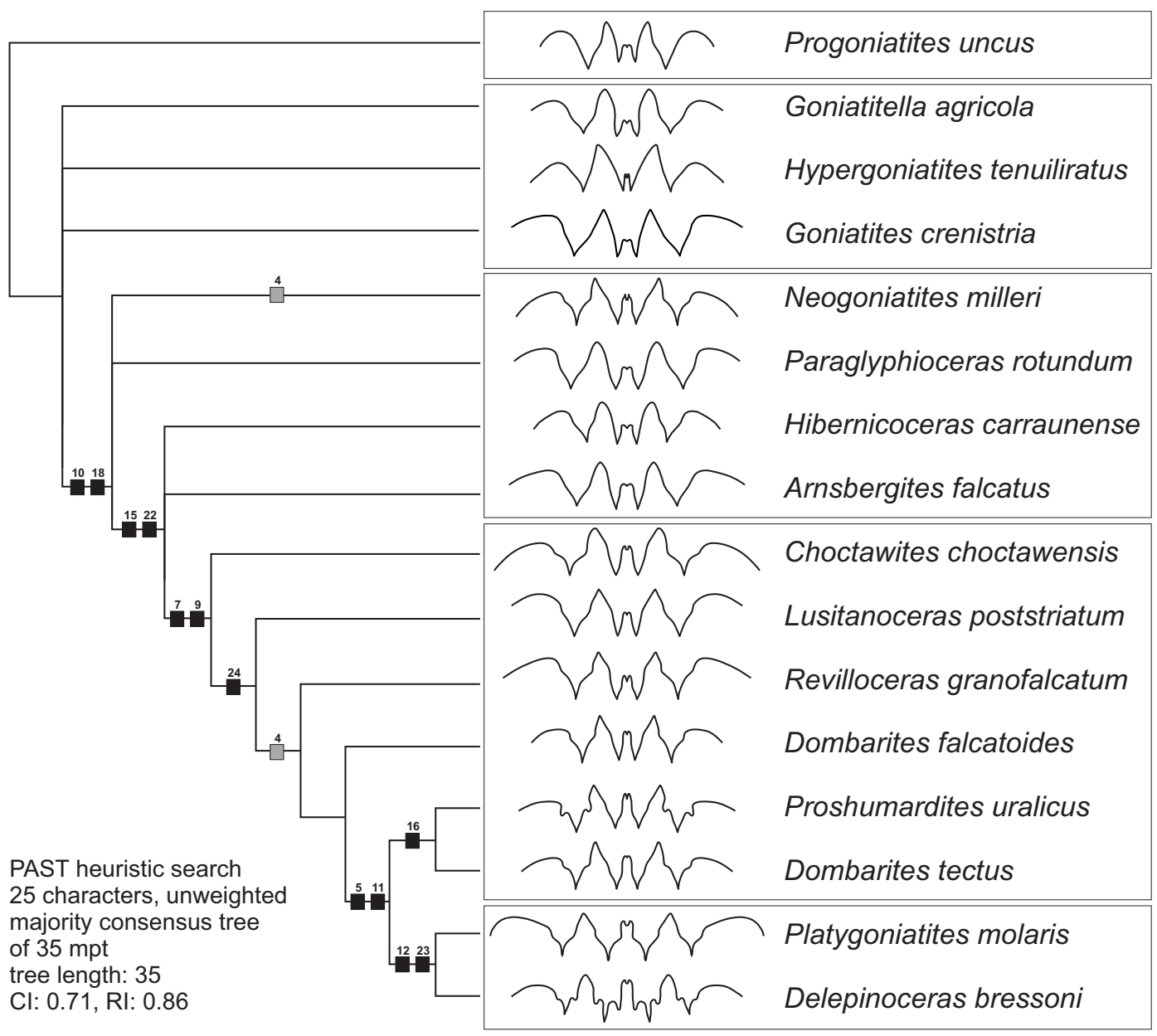

Figure 10. Cladogram of selected genera, represented by well-known species, of the superfamily Goniatitaceae.

Family Delepinoceratidae Ruzhencev, 1957

Family diagnosis: Representatives of the superfamily Goniatitaceae with advanced suture lines possessing a Y-shaped external lobe and a tectiform ventrolateral saddle. The adventive lobe and also the prongs of the external lobe show the tendency to become tridentate.

Discussion: There exist three diverging concepts about the classification of the advanced goniatitid species and genera. Ruzhencev and Bogoslovskaya (1971, 1978) separated the families Delepinoceratidae (including Platygoniatites and Delepinoceras) and Agathiceratidae (including Dombarites, Pericleites, Proshumardites, and Agathiceras) on the basis of the subdivision mode of the external lobe, thus delineating two independent evolutionary lineages. Leonova (2002, 2011) doubted the assignment of Agathiceras in the order Goniatitida and transferred it into the order Tornoceratida (which has usually only been accepted as a suborder within the Goniatitida). Finally, Kullmann et al. (2007) and Kullmann (2009a, b) separated Agathiceras and closely related forms in the independent superfamily Agathiceratoidea within the suborder Goniatitina. In Kullmann's concept, the genera Dombarites and Proshumardites are grouped in the subfamily Dombaritinae within the family Delepinoceratidae.

If Agathiceras is excluded from the discussion of the phylogeny of the family Goniatitidae and its descendants (for instance, if the central or sub-central position of the siphuncle in the juvenile stage is been taken as a reason for separation on higher taxonomic levels), then the phylogenetic analysis (see below) speaks for the extension of the family Delepinoceratidae to also include the subfamily Dombaritinae (Kullmann, 2009a). This subfamily, however, also requires re-definition to include the genera Revilloceras, Lusitanoceras, and Choctawites.

For resolving the phylogenetic relationships of the goniatitid ammonoid genera, we performed a cladistic analysis based on the character matrix of Korn (1997a). In contrast to that analysis, we used Progoniatites uncus Korn, Bockwinkel and Ebbighausen, 2010 as the outgroup species and included three more ammonoid species in the new analysis, Choctawites choctawensis, Revilloceras granofalcatum, and 
Dombarites falcatoides. We included a new character, the presence of shell constrictions, in the matrix.

The heuristic cladistics analysis performed with PAST (Hammer et al., 2009) led to 35 most parsimonious trees of 35 steps length, of which a majority consensus tree was formed (Fig. 10). This tree shows some unresolved branches but demonstrates that a crown group is well established with the genera Choctawites, Lusitanoceras, Revilloceras, Dombarites, Proshumardites, Platygoniatites, and Delepinoceras, which are all characterized by the apomorphies of a Y-shaped external lobe and a tendency towards a tectiform ventrolateral saddle. This clearly defined clade can best be described as the family Delepinoceratidae. One has, however, to take into account that a similar tendency of sutural development also occurs in the more conservative lineage leading to Neogoniatites.

The cladogram also shows that Choctawites is more plesiomorphic than the other of the genera, which are all defined by the presence of outer shell constrictions in the juvenile stage. The crown group is subdivided into two independent clades, one represented by the advanced Dombarites species D. tectus and Proshumardites and the other represented by the genera Platygoniatites and Delepinoceras.

Subfamily Dombaritinae (in Kullmann et al., 2007)

Subfamily diagnosis: Delepinoceratidae with advanced, moderately wide external lobes (usually between 0.60 and 0.90 , measured at half height, of the external lobe depth), and median saddles with a height of 0.50 to 0.75 of the external lobe depth. External lobe Y-shaped and undivided.

Included genera:

Choctawites n. gen.

Lusitanoceras Pereira de Sousa, 1923

Revilloceras Wagner-Gentis, 1980

Dombarites Librovitch, 1957

Proshumardites Rauser-Tschernoussowa, 1928

Deleshumardites Kullmann, 2007

Discussion: Distinctive Late Viséan to early Serpukhovian goniatitids with advanced lobes (especially with broader, more deeply divided external lobe) have an almost cosmopolitan distribution (Librovitch, 1957; Gordon, 1965; Ruzhencev and Bogoslovskaya, 1970, 1971; Drahovzal and Quinn, 1972; Wagner-Gentis, 1980; Webster et al., 1984; Korn et al., 1999; Nikolaeva and Konovalova, 2005; Klug et al., 2006). Until recently, it was thought that this morphological complex formed an essentially monophyletic clade that dispersed during the Late Viséan, evolving from the advanced goniatitid Lusitanoceras (Korn, 1988, 1997b; Kullmann, 2009a). Cross sections of various specimens belonging to Lusitanoceras were shown by Kullmann and Pitz (1980), Kusina (1987), Korn (1988, 1997b), Kusina and Yatskov (1999) and Nikolaeva and Konovalova (2005); all sections possess a rather long subevolute juvenile stage.
Nikolaeva and Konovalova (2005) figured cross sections of a series of specimens from the Urals that were all referred to as the genus Dombarites by Ruzhencev and Bogoslovskaya (1971) and concluded that the shapes of the early whorls in this are very different to those of the genus Lusitanoceras. Consequently, Nikolaeva and Konovalova (2005) postulated that Dombarites sensu stricto did not evolve from Lusitanoceras, but directly from the genus Goniatites. Indeed, the figured cross sections of Dombarites with subinvolute inner whorls suggest that the umbilical width in the inner whorls are more similar to Goniatites; however, one has to keep in mind that there is no reason to assume that evolutionary pathways always proceed in the same trend (e.g. from involute to evolute inner whorls); Dombarites, with its less widely umbilicate inner whorls may also have been derived from more evolute forms. Furthermore, the suture lines of all of the genera assembled in the subfamily Dombaritinae are very similar in great detail, speaking for very close relationships and obviously ruling out homoplasy.

A more detailed subdivision of the various forms often assembled in the genus Dombarites requires the separation of genera on the base of morphology of the inner whorls, ornament and suture line details (Table 6). For this reason we describe the new genus Choctawites to accommodate the North American species "Goniatites choctawensis Shumard, 1863", "G. kentuckiensis Miller, 1889" and "G. cumminsi Hyatt, 1893" and revive the genus Revilloceras WagnerGentis, 1980 for superficially similar species known from the Cantabrian Mountains of Spain and the Anti-Atlas of Morocco.

\section{Choctawites n. gen.}

Type species: Goniatites choctawensis Shumard, 1863.

Genus diagnosis: Dombaritinae with subevolute to evolute inner whorls; the umbilicus becomes closed in early ontogeny. Whorl profile with parallel or subparallel flanks, conch in juveniles widest at some distance from the umbilicus. Externally expressed constrictions extremely rare or absent. Growth lines slightly biconvex and rectiradiate; external sinus shallow. External lobe Y-shaped, very narrow or narrow, usually with slightly curved flanks.

Included species:

choctawensis: Goniatites choctawensis Shumard, 1863, p. 109; Oklahoma.

cumminsi: Glyphioceras cumminsi Hyatt, 1893, p. 467; Texas.

kentuckiensis: Goniatites kentuckiensis Miller, 1889, p. 439; Kentucky.

Discussion: All Late Viséan-early Serpukhovian goniatitid ammonoids with prominent adult spiral ornament found in North America can be readily divided into two major groups (Gordon, 1965), (1) those with external shell constrictions and (2) those in which constrictions are developed as internal 
Table 6. Characteristics of genera within the subfamily Dombaritinae.

\begin{tabular}{|c|c|c|c|c|}
\hline & Choctawites & Lusitanoceras & Revilloceras & Dombarites \\
\hline $\begin{array}{l}\text { General shape of inner } \\
\text { whorls }\end{array}$ & subevolute to evolute & subevolute & evolute & subinvolute \\
\hline $\begin{array}{l}\text { Whorl profile of inner } \\
\text { whorls }\end{array}$ & $\begin{array}{l}\text { whorls widest at some } \\
\text { distance from umbilical } \\
\text { margin, flanks diverg- } \\
\text { ing or subparallel, } \\
\text { trapezoidal }\end{array}$ & $\begin{array}{l}\text { whorls widest at umbil- } \\
\text { ical margin, flanks con- } \\
\text { verging }\end{array}$ & $\begin{array}{l}\text { whorls widest at umbil- } \\
\text { ical margin, flanks con- } \\
\text { verging }\end{array}$ & variable \\
\hline Constrictions & only on steinkern & on shell surface & on shell surface & often on shell surface \\
\hline Coiling of inner whorls & rounded & usually triangular & triangular & $\begin{array}{l}\text { triangular at some } \\
\text { species }\end{array}$ \\
\hline $\begin{array}{l}\text { Ornament in the } \\
\text { subadult stage }\end{array}$ & fine spiral lines & coarse spiral lines & coarse spiral lines & variable \\
\hline $\begin{array}{l}\text { Ornament in the adult } \\
\text { stage }\end{array}$ & $\begin{array}{l}\text { fine spiral lines, falcate } \\
\text { transverse ornament }\end{array}$ & $\begin{array}{l}\text { coarse spiral lines, oc- } \\
\text { casionally falcate trans- } \\
\text { verse } \\
\text { ornament }\end{array}$ & $\begin{array}{l}\text { coarse spiral lines, fal- } \\
\text { cate transverse orna- } \\
\text { ment }\end{array}$ & variable \\
\hline $\begin{array}{l}\text { Height of median sad- } \\
\text { dle }\end{array}$ & $\begin{array}{l}0.60 \text { of external lobe } \\
\text { depth }\end{array}$ & $\begin{array}{l}0.50-0.55 \text { of external } \\
\text { lobe depth }\end{array}$ & $\begin{array}{l}0.50-0.55 \text { of external } \\
\text { lobe depth }\end{array}$ & $\begin{array}{l}0.65-0.75 \text { of external } \\
\text { lobe depth }\end{array}$ \\
\hline Shape of external lobe & weakly Y-shaped & weakly Y-shaped & strongly Y-shaped & weakly Y-shaped \\
\hline $\begin{array}{l}\text { Width of external lobe } \\
\text { at half depth }\end{array}$ & 0.80 of E lobe depth & 0.65 of E lobe depth & 0.70 of E lobe depth & $\begin{array}{l}0.70-0.85 \text { of } E \text { lobe } \\
\text { depth }\end{array}$ \\
\hline $\begin{array}{l}\text { Shape of external lobe } \\
\text { prongs }\end{array}$ & V-shaped & V-shaped & lanceolate & V-shaped or lanceolate \\
\hline $\begin{array}{l}\text { Flanks of adventive } \\
\text { lobe }\end{array}$ & sinuous & slightly sinuous & with inflexion & with inflexion \\
\hline
\end{tabular}

shell thickenings and thus only visible on the internal mould. This subdivision largely parallels the whorl cross sections, of which the first group possesses more or less trapezoidal early whorl profiles (in which the conch is widest at some distance from the umbilicus), and the second group shows "normal" whorl profiles with flanks converging from the umbilical wall towards the venter.

Examinations of collections from the Moorefield Formation, Caney Shale, and Barnett Shale show that the two morphological groups have very little morphological or ornamental overlap. Trapezoidal forms are consistently crenistriate or cross lirate to about $15 \mathrm{~mm}$ diameter. In contrast, the normal forms develop strong spiral ornament already by $10 \mathrm{~mm}$ conch diameter and can exhibit sub-triangular coiling. Furthermore, at any given locality or horizon in the eastern USA, either trapezoidal or rounded forms can totally dominate a sample.

Three possible hypotheses could explain this dimorphic pattern: (1) broad intraspecific variation; (2) sexual dimorphism, and (3) two different taxonomic groups are present in North America. Given the lack of morphological interme- diates between trapezoidal and normal forms, we reject the first hypothesis. Regarding the second hypothesis, the stratigraphically lower normal forms associated with Sulcogirtyoceras limatum (Miller and Faber, 1892) are readily referable to Lusitanoceras because they possess the characteristic early ontogeny, sutural shape, and ornament (particularly with granulated spiral lines) of that genus. In fact, these forms are so close to the European species of Lusitanoceras that they have been referred to as "Goniatites granosus Portlock, 1843" since the early 1960s (Gordon, 1965). While we doubt the species assignment, the referral of the North American material to the genus Lusitanoceras is correct. If the trapezoidal forms are simply sexual dimorphs of Lusitanoceras, it would be expected that this same dichotomy would exist in the European and North American occurrences. Instead, the trapezoidal forms are found almost exclusively in Marathon-Ouachita-Appalachian foreland basin system, being unknown from Europe and extremely rare in the Antler Foreland Basin. This pushes us to accept that the trapezoidal forms are a distinct taxonomic entity endemic to Laurentia 
(North America). Since they cannot be accommodated in any existing genus, we erect the new genus Choctawites for them.

Choctawites cumminsi (Hyatt, 1893) (Figs. 11a, b and 12)

1893 Goniatites cumminsi Hyatt, p. 467, pl. 47, figs. 33-43. 1965 Goniatites choctawensis. - Gordon, pl. 19, figs. 1-12, text-fig. 44E, F [only].

Lectotype: Specimen UT 12031 (designated by Cloud and Barnes, 1948); illustrated by Gordon (1965, pl. 19, figs. 1$6)$.

Type locality and horizon: 5 miles west of Lampasas (Lampasas County, Texas); Barnett Shale.

Diagnosis: Choctawites with a thickly pachyconic to globular conch between 2 and $12 \mathrm{~mm}$ diameter ( $\mathrm{ww} / \mathrm{dm}=0.85$ $0.95)$ and thickly pachyconic conch $(\mathrm{ww} / \mathrm{dm}=0.70)$ at $20 \mathrm{~mm}$ diameter. Umbilicus moderately narrow to moderately wide in early ontogeny (uw / $\mathrm{dm}=0.25-0.35$ at $1.5-$ $2 \mathrm{~mm}$ diameter) and very narrow in all stages larger than $4 \mathrm{~mm}$ diameter (uw / dm 0.05-0.08). Umbilical wall convexly rounded in all stages, very short early juvenile stage with slightly trapezoidal whorl cross section. Aperture low (WER $=1.65-1.70$ throughout ontogeny). Ornament with about 120 spiral lines and crenulated, slightly biconvex, and rectiradiate growth lines; external sinus shallow. Falcate ornament begins at $40 \mathrm{~mm} \mathrm{dm}$.

Material: 43 specimens (NPL 68497 through NPL 68539), all from sample 00TXCU-27. The material consists of brown to black coloured phosphatic steinkerns, which have varying amounts of shell preserved on them. Shell occasionally exhibits iridescent colour in small areas. Most of the inner phragmocones (diameter less than $10 \mathrm{~mm}$ ) were not filled with minerals and weathered out rapidly or were not preserved, leaving a hollow space in the specimen. Some of these small interior phragmocones are exceptionally well preserved when freshly exposed and show the fine details of the septa and shell. The largest intact specimens were about $20 \mathrm{~mm}$ in diameter. Only fragments of larger specimens were collected.

Description: The conch cross section of the small specimen NPL 68499 (10 mm conch diameter) shows a globular shape $(\mathrm{ww} / \mathrm{dm}=0.86)$ and a very narrow umbilicus (uw $/ \mathrm{dm}=$ 0.06 ) with broadly rounded flanks and venter (Fig. 12e). The inner whorls show crescent-shaped whorl profiles and a moderately wide umbilicus; the highest uw / dm ratio with 0.34 occurs at $1.2 \mathrm{~mm}$ conch diameter. In the growth interval between 5 and $10 \mathrm{~mm}$ conch diameter, the conch is widest at some distance from the umbilicus.

The conch cross section from the Sierra Diablo specimen is very similar to four cross sections (specimens 26-13, 262, 26b, 26-10) produced by R. Kant (Tübingen) of material from San Saba (original specimens identified by M. Gordon in the USNM; acetate peels in the collections of the GPI Tübingen). The San Saba topotypes only differ in the slightly
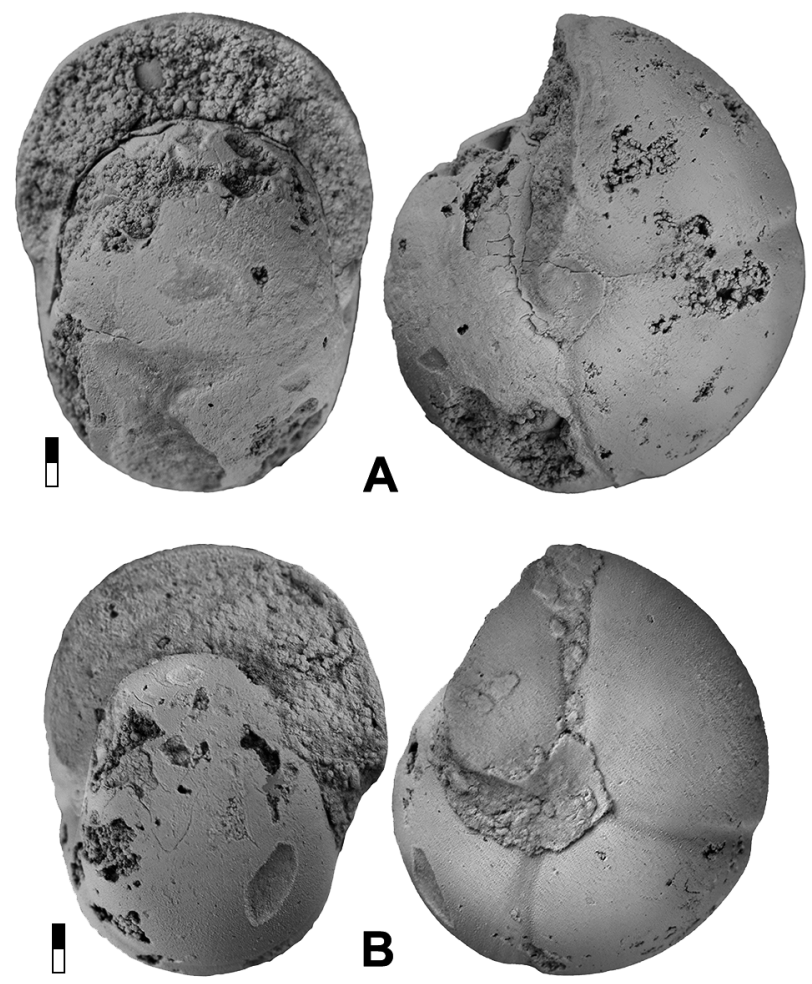

Figure 11. Choctawites cumminsi (Hyatt, 1893) from bed 25 (sample 00TXCU-27) of the Figure 2 Ranch section; both $\times 2.5$. (a) Specimen NPL 68497. (b) Specimen NPL 68498.

more pronounced trapezoidal whorl profile and the more subparallel flanks (Fig. 12a-d).

Conchs are thickly pachyconic at $20 \mathrm{~mm}$ (e.g. specimen NPL 68497; Fig. 11a), with a very narrow umbilicus and moderately depressed whorls ( $\mathrm{ww} / \mathrm{dm}=0.74 ; \mathrm{ww} / \mathrm{wh}=$ 1.36). Flanks and venter are continuously rounded and the aperture is low (WER = 1.64). The specimen is an internal mould without shell remains; the body chamber has nearly the length of a volution. The internal mould shows shallow constrictions with irregular distances; they extend linearly across the flanks and turn forward for a low and wide ventral projection.

The slightly smaller specimen NPL 68497 (17 mm dm) largely resembles the previous specimen. The internal mould has four prominent constrictions, which probably follow the growth lines in their course, are almost rectiradiate, bearing only a slight forward inflection or are salient over the ventral area (Fig. 11b).

The smallest specimens (e.g. specimen NPL 68501) are $7 \mathrm{~mm}$ in diameter. By that stage, the conch is starting to change from sub-trapezoidal (strongly recurved flanks) to rounded whorl profiles. As a result, the trapezoidal phase, which is only weakly developed in this taxon, was only seen on cross-sectioned conchs. 


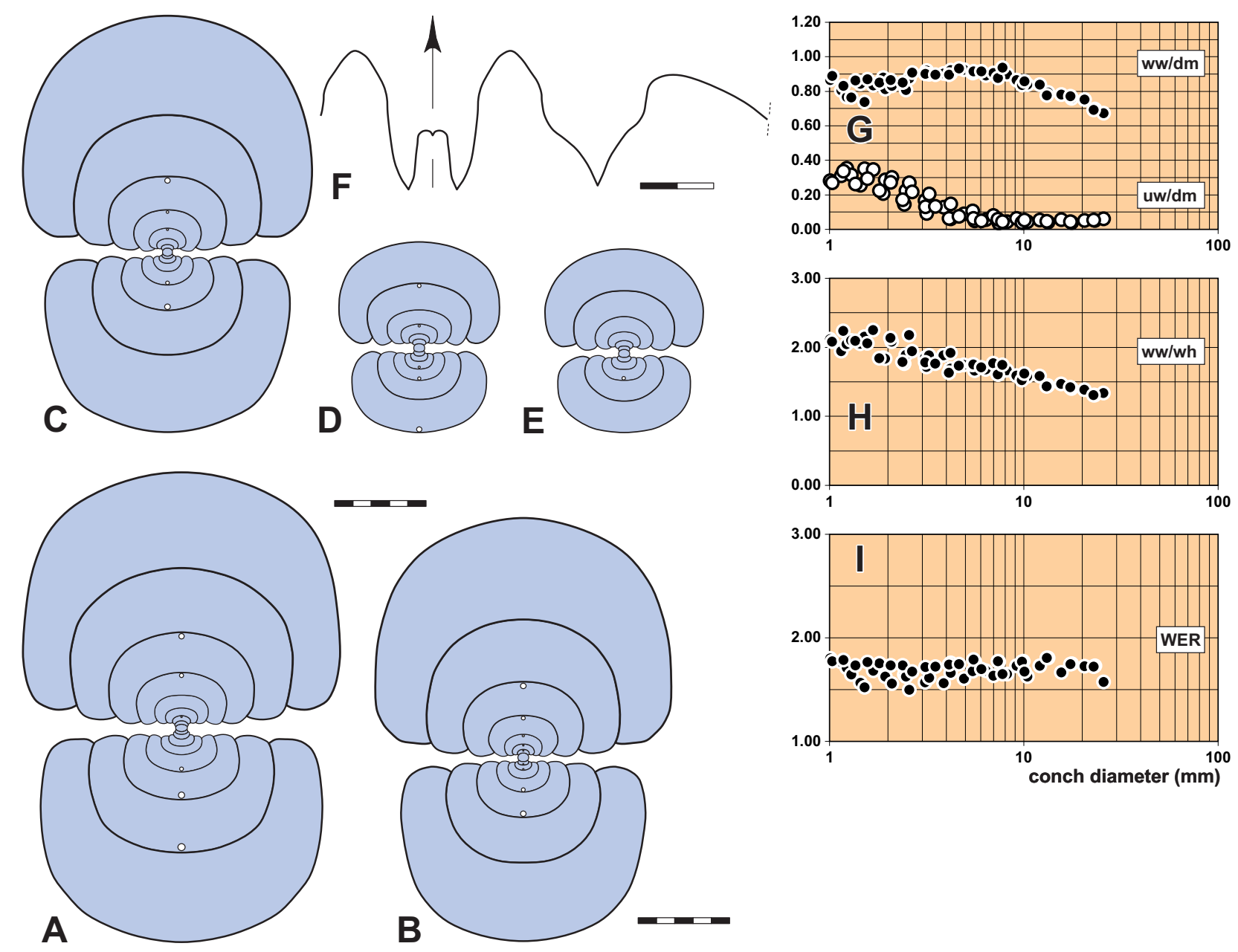

Figure 12. Choctawites cumminsi (Hyatt, 1893) from San Saba (a-d) and the Figure 2 Ranch section (e, f). (a) Cross section of specimen 2613 from San Saba; $\times 2.5$. (b) Cross section of specimen 26-2 from San Saba; $\times 2.5$. (c) Cross section of specimen $26 \mathrm{~b}$ from San Saba; $\times 2.5$. (d) Cross section of specimen 26-10 from San Saba; $\times 2.5$. (e) Cross section of specimen NPL 68499 from bed 25 (sample 00TXCU27) of Figure 2 Ranch; $\times 2.5$. (f) Suture line of specimen NPL 68500 from bed 25 (sample 00TXCU27) of Figure 2 Ranch, at 14.4 mm diameter, $11.3 \mathrm{~mm}$ ww, $7.2 \mathrm{~mm}$ wh; $\times$ 5.0. (g-i), Ontogenetic development of the conch width index (ww / dm), umbilical width index (uw / dm), and WER of all available specimens (the cross sections of specimens (a-d) from San Saba were produced by R. Kant; the original specimens are stored in the collections of the USNM, acetate peels are stored in the collections of the GPI Tübingen).

Specimen NPL 68500 shows the suture line of a specimen in the intermediate growth stage (at $14.4 \mathrm{~mm} \mathrm{dm}$ ). It possesses a Y-shaped external lobe with sinuous flanks. The external lobe has, measured at half depth, 0.64 of the external lobe depth and is 1.25 times wider than the ventrolateral saddle. The median saddle reaches a height of 0.42 of the external lobe depth. The ventrolateral saddle is tectiform and subacute (Fig. 12f).

Ornament is only commonly preserved on the larger whorl fragments, but smaller specimens show crenistriate ornament up to diameters of approximately $15 \mathrm{~mm}$, after which it changes to strong longitudinal lirae numbering about 1920 per $5 \mathrm{~mm}$.

Discussion: Forms we refer to Choctawites have historically been attributed to three species; "Goniatites choctawensis
Shumard, 1863", "Goniatites cumminsi Hyatt, 1893", and "Goniatites kentuckiensis Miller, 1889". Gordon (1965) regarded G. cumminsi as a junior synonym of G. choctawensis, a view supported in nearly every subsequent paper. Recently, Work and Mason (2009a) synonymized G. kentuckiensis with G. choctawensis and followed Ruzhencev and Bogoslovskaya (1971) in assigning G. choctawensis to Dombarites, which left $G$. choctawensis as the only valid species in this group. After reviewing the literature and numerous specimens, we have concluded that all three established species of the "trapezoidal" group (G. kentuckiensis, G. choctawensis, and G. cumminsi) are valid and represent a stratigraphic and possibly evolutionary succession.

The stratigraphically oldest species is Choctawites kentuckiensis, which is associated with Sulcogirtyoceras lima- 
Table 7. Conch ontogeny of Choctawites cumminsi (Hyatt, 1893); mainly based on specimens from San Saba (Elias Coll; cross sections by R. Kant, Tübingen).

\begin{tabular}{llll}
\hline $\mathrm{dm}$ & Conch shape & Whorl cross section shape & Aperture \\
\hline $1.5 \mathrm{~mm}$ & $\begin{array}{l}\text { thickly pachyconic; subinvolute or subevolute } \\
(\text { ww } / \mathrm{dm}=0.75-0.85 ; \text { uw } / \mathrm{dm}=0.25-0.35)\end{array}$ & $\begin{array}{l}\text { strongly depressed; very strongly embracing } \\
(\text { ww } / \text { wh }=2.00-2.25 ; \text { IZR }=0.45-0.50)\end{array}$ & $\begin{array}{l}\text { low } \\
\text { (WER }=1.55-1.65)\end{array}$ \\
\hline $5 \mathrm{~mm}$ & $\begin{array}{l}\text { globular; involute } \\
(\text { ww } / \mathrm{dm}=0.90 ; \text { uw } / \mathrm{dm}=0.05-0.10)\end{array}$ & $\begin{array}{l}\text { moderately depressed; very strongly embracing } \\
(\text { ww } / \text { wh }=1.65 ; \text { IZR }=0.55-0.60)\end{array}$ & $\begin{array}{l}\text { low } \\
\text { (WER }=1.60-1.75)\end{array}$ \\
\hline \multirow{2}{*}{$10 \mathrm{~mm}$} & $\begin{array}{l}\text { thickly pachyconic or globular; involute } \\
(\text { ww } / \mathrm{dm}=0.85 ; \text { uw } / \mathrm{dm}=0.05)\end{array}$ & $\begin{array}{l}\text { moderately depressed; very strongly embracing } \\
(\text { ww } / \text { wh }=1.55 ; \text { IZR }=0.50-0.60)\end{array}$ & low \\
& (WER $=1.60-1.75)$ \\
\hline $25 \mathrm{~mm}$ & thinly pachyconic; involute & weakly depressed; very strongly embracing & low \\
& $($ ww $/ \mathrm{dm}=0.70 ;$ uw $/ \mathrm{dm}=0.05)$ & $($ ww $/$ wh $=1.30 ;$ IZR $=0.55)$ & (WER $=1.60-1.70)$ \\
\hline $50 \mathrm{~mm}$ & thickly discoidal; involute & weakly depressed & \\
& $($ ww $/ \mathrm{dm}=0.58 ;$ uw $/ \mathrm{dm}=0.08)$ & $($ ww $/$ wh $=1.15)$ & \\
\hline
\end{tabular}
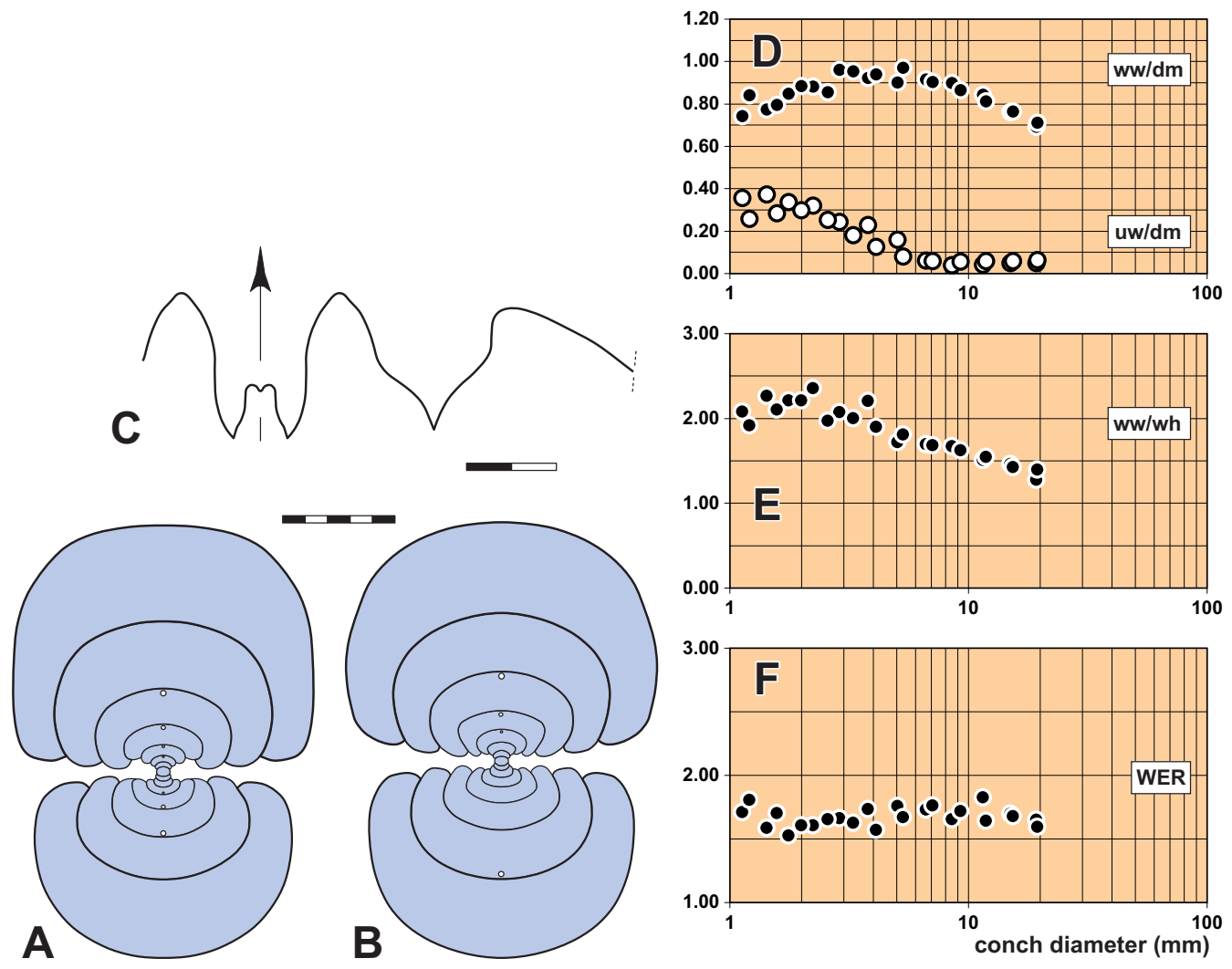

Figure 13. Choctawites kentuckiensis (Miller, 1889). (a) Cross section of specimen 57a from Moorefield, Arkansas; $\times 2.5$. (b) Cross section of specimen MB.C.25470 from Moorefield, Arkansas; $\times 2.5$. (c) Suture line of specimen MB.C.25471 from Moorefield, Arkansas, at $14.1 \mathrm{~mm}$ diameter, $10.2 \mathrm{~mm}$ ww, $6.6 \mathrm{~mm}$ wh; $\times 5.0$. (d-f) Ontogenetic development of the conch width index (ww / dm), umbilical width index (uw / dm), and WER of all available specimens (cross section (a) was produced by R. Kant; the original specimen is stored in the collections of the University of Iowa, acetate peels are stored in the collections of the GPI Tübingen).

tum and can be differentiated from the other species because it possesses a moderately well-developed trapezoidal shape (Fig. 13a, b) and late development of falcate ornament (typically appearing at diameters greater than $50 \mathrm{~mm}$ ). This taxon was referred to as Dombarites choctawensis by Work and Mason (2009a). However, type specimens of Choctawites choctawensis consistently develop falcations by $40-45 \mathrm{~mm}$ diameter. Also, the early ontogenies of Ch. choctawensis and 

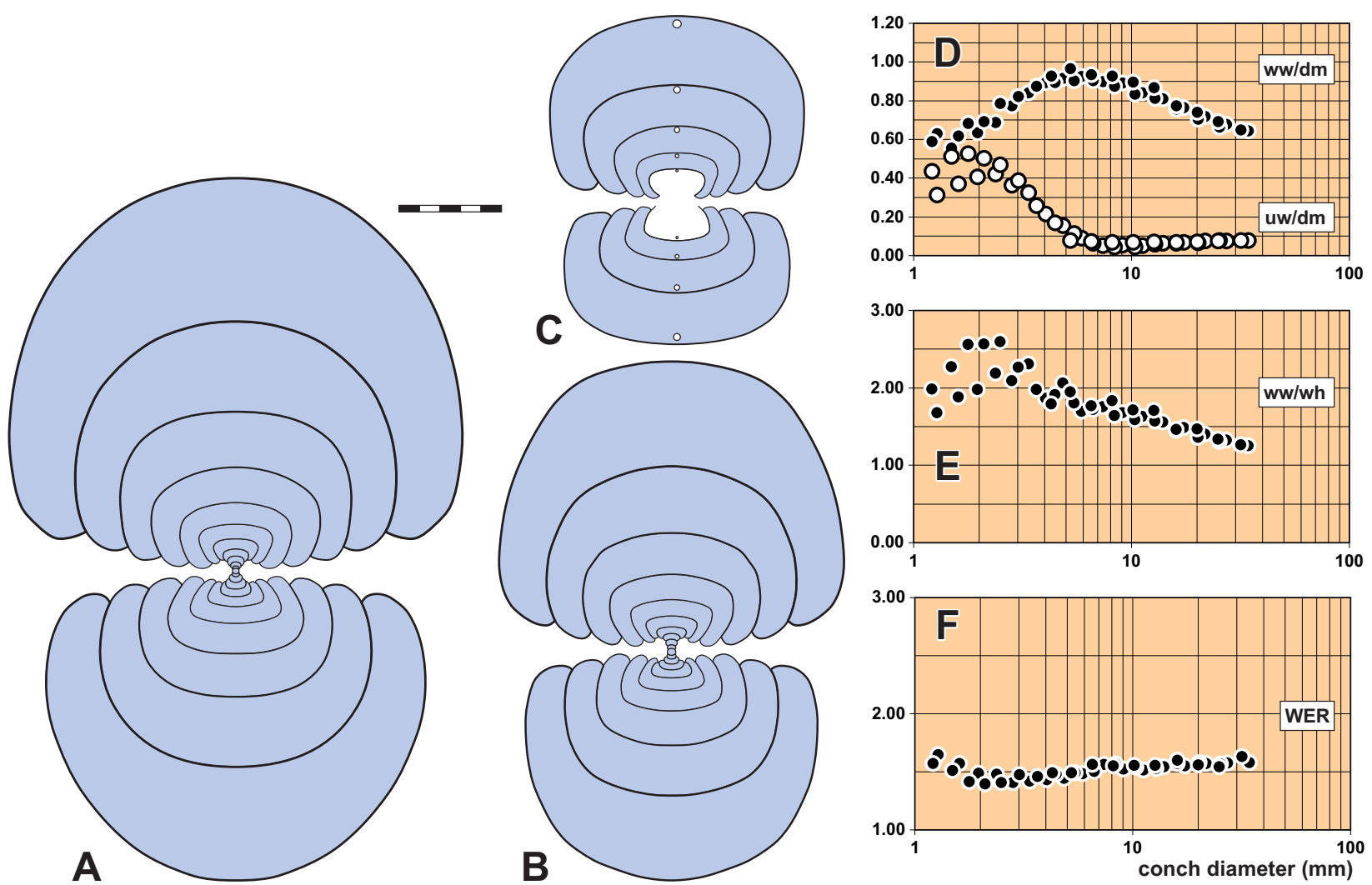

Figure 14. Choctawites choctawensis (Shumard, 1863). (a) Cross section of topotype USNM 119504 from Brushy Creek, Oklahoma; $\times 2.5$ (from Gordon, 1965). (b) Cross section of specimen 71 from Ada, Oklahoma; × 2.5. (c) Cross section of specimen 26-1 from San Saba; $\times 2.5$. (d-f), Ontogenetic development of the conch width index (ww / dm), umbilical width index (uw / dm), and whorl expansion rate (WER) of all available specimens (the cross sections of specimens (b) and (c) from Ada and San Saba were produced by R. Kant; the original specimens is stored in the collections of the USNM, acetate peels are stored in the collections of the GPI Tübingen).

Table 8. Conch dimensions and ratios for Choctawites cumminsi (Hyatt, 1893) from the type area and the Sierra Diablo.

\begin{tabular}{lrrrrrrrrrr}
\hline Specimen & dm & ww & wh & uw & ah & ww / dm & ww / wh & uw / dm & WER & IZR \\
\hline Paratype-UT 12032 & 50.0 & 29.0 & 26.0 & 4.0 & - & 0.58 & 1.12 & 0.08 & - & - \\
Holotype-UT 12031 & 20.8 & 14.6 & 11.5 & 1.8 & 4.7 & 0.70 & 1.27 & 0.09 & 1.67 & 0.59 \\
NPL 68502 & 19.8 & 14.5 & 11.4 & 1.6 & 4.5 & 0.73 & 1.27 & 0.08 & 1.67 & 0.61 \\
NPL 68497 & 19.6 & 14.6 & 10.7 & 2.0 & 4.3 & 0.74 & 1.36 & 0.10 & 1.64 & 0.60 \\
NPL 68503 & 17.6 & 13.5 & 9.6 & 1.9 & 3.9 & 0.77 & 1.41 & 0.11 & 1.65 & 0.59 \\
NPL 68498 & 17.2 & 12.9 & 8.9 & 1.9 & 4.1 & 0.75 & 1.45 & 0.11 & 1.72 & 0.54 \\
NPL 68504 & 15.3 & 12.5 & 8.4 & 1.8 & - & 0.82 & 1.49 & 0.12 & - & - \\
NPL 68505 & 14.8 & 11.9 & 8.0 & 1.8 & 3.5 & 0.80 & 1.49 & 0.12 & 1.72 & 0.56 \\
NPL 68500 & 14.5 & 11.6 & 7.7 & 2.1 & 3.3 & 0.80 & 1.51 & 0.14 & 1.68 & 0.57 \\
NPL 68499 & 12.4 & 9.8 & 6.0 & 1.4 & 2.8 & 0.79 & 1.63 & 0.11 & 1.67 & 0.53 \\
NPL 68501 & 6.9 & 6.2 & - & - & - & 0.90 & - & - & - & - \\
\hline
\end{tabular}

Ch. kentuckiensis are similar, but the former has a much stronger expression of the trapezoidal shape. These two criteria can be used to readily differentiate between the two species. There is an apparent facies difference in the occurrence pattern of the two species, with Choctawites kentuckiensis being known from shallower water deposits includ- ing a carbonate platform and pro-deltaic mudstone facies in the Appalachian and Ouachita foreland basins (Gordon, 1965; Work and Mason, 2009a), and Ch. choctawensis occurring in the deeper water sequences of the Caney and Barnett shales. The exclusion of the latter from shallow water 
facies may have resulted from the sea level fall recorded by the Batesville Sandstone wedge in Arkansas.

The stratigraphically next species we can recognize in succession is the type species, Ch. choctawensis, which has the unique combination of early appearance of falcations and a strongly developed trapezoidal phase (Fig. 14a-c). Ch. choctawensis is associated with a more advanced species of Sulcogirtyoceras, S. . cf. S. ornatissimum. It is known widely from the Caney Shale of Oklahoma, e.g. specimen USNM 119505 from USGS locality 2078A (Gordon, 1965, fig. 44G, H) and specimen Kant71 (Elias Collection) from 6 miles SE of Ada along Highway 99 (Pontotoc County, Oklahoma), the Barnett Shale of central Texas (specimen Kant26-1), and tentatively, the Batesville Sandstone of Arkansas (Gordon, 1965).

The stratigraphically youngest species, Ch. cumminsi, is a form whose distinct, but reduced, trapezoidal phase (Fig. 12a-e), more narrowly umbilicate early whorls, and early appearance of falcations are highly definitive. The species can still be differentiated from the other species of Choctawites using the brief or even absent trapezoidal stage. Ch. cumminsi is known mostly from the Barnett Shale of Texas, but almost certainly occurs in the Caney Shale of Oklahoma and Arkansas (e.g. specimen USNM 119502; Gordon 1965, fig. 44e, f). This species is associated with Sulcogirytoceras ornatissimum (Miller and Youngquist, 1948) and species of Pachylyroceras, which together comprise one of the youngest Viséan ammonoid assemblages we can recognize in the eastern USA. Since the Sierra Diablo specimens all exhibit the characteristic reduced trapezoidal stage, we refer to them as Ch. cumminsi.

Superfamily Neoglyphiocerataceae Plummer and Scott, 1937

Family Neoglyphioceratidae Plummer and Scott, 1937

\section{Pachylyroceras Ruzhencev and Bogoslovskaya, 1971}

Type species: Lyrogoniatites cloudi Miller and Youngquist, 1948 [original designation].

Genus diagnosis: Representatives of the family Neoglyphioceratidae with subevolute conch, which becomes more evolute in the adult stage. 20-30 coarse spiral lines, growth lines, and shell constrictions concavo-convex with shallow ventral sinus. Suture line with rather narrow external lobe, usually with slightly sinuous flanks.

Included species:

cloudi: Lyrogoniatites cloudi Miller and Youngquist, 1948, p. 660; Texas.

utahense: Lyrogoniatites utahensis Miller, Youngquist and Nielsen, 1952, p. 154; Utah.

Discussion: When they introduced the genus Pachylyroceras, Ruzhencev and Bogoslovskaya (1971) assumed that certain Uralian specimens and the types for Lyrogoniatites cloudi
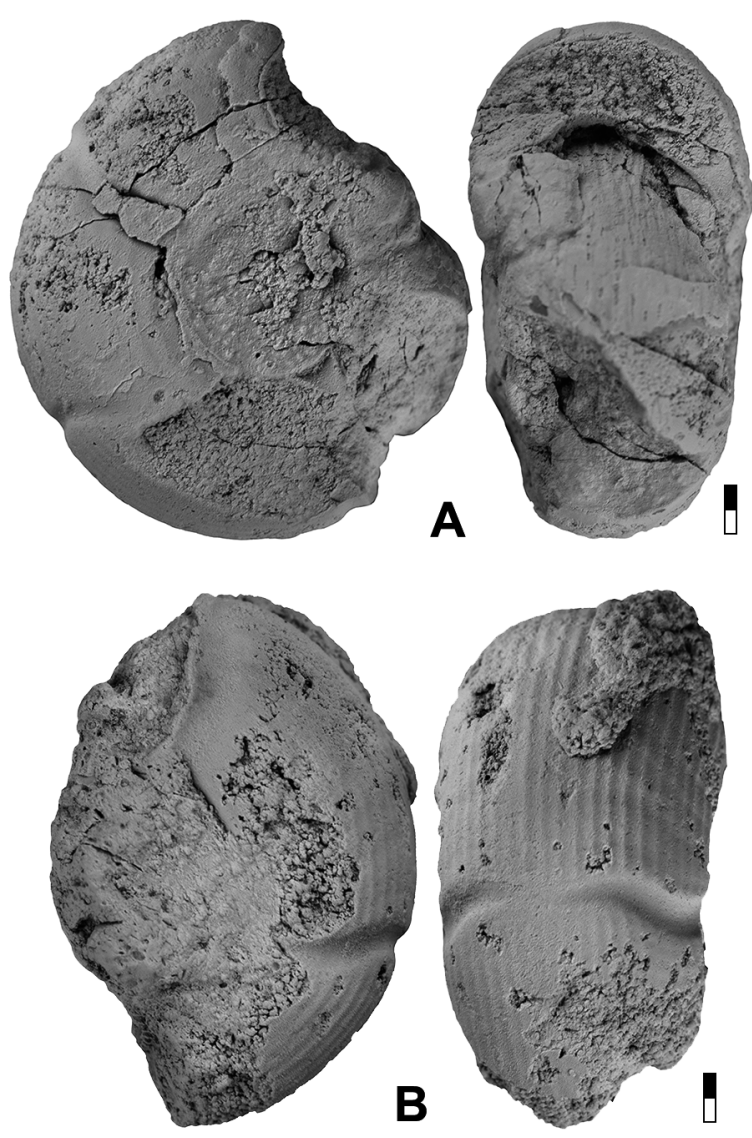

Figure 15. Pachylyroceras cloudi (Miller and Youngquist, 1948) from bed 25 (sample 00TXCU-27) of the Figure 2 Ranch section; both $\times 2.5$. (a) Specimen NPL 68540. (b) Specimen NPL 68541 .

from the Barnett Shale were conspecific. As a result, they based Pachylyroceras on the types of $L$. cloudi from Texas, rather than the Uralian material they had in their collections and erected three new species, $P$. angustum, $P$. consequens, and $P$. constrictum. We see significant differences in the course of growth lines in all of the Uralian specimens (ventral salient) versus the Texas types of Pachylyroceras (ventral sulcus), and conclude that the genus, which is closely related to Neoglyphioceras, is currently known only from North America.

This excludes all of the Uralian material from Pachylyroceras, and given that there is no existing genus to accommodate these widely umbilicate Neoglyphioceras-like forms with ventral salient in their growth lines and constrictions, we erect the new genus Uralyroceras for the Uralian species (see below).

According to its conch morphology, suture line, and ornament, Pachylyroceras has an intermediate position between Neoglyphioceras and Lyrogoniatites. It possesses the type of shell constrictions with ventral sinus of Neoglyphioceras but the subevolute conch morphology of Lyrogoniatites. In the suture line, Pachylyroceras shows the sinuous flanks of the 
external lobe like Neoglyphioceras, but at the same time, the external lobe is rather narrow with weakly diverging flanks like in Lyrogoniatites.

\section{Pachylyroceras cloudi (Miller and Youngquist, 1948) (Figs. 15a, $b$ and 16c)}

1909 Goniatites newsomi. - Girty, pl. 12, figs. 11, 11a. 1948 Lyrogoniatites cloudi Miller and Youngquist, p. 660, pl. 94, figs. 1-3.

1965 Neoglyphioceras cloudi. - Gordon, pl. 20, figs. 12-14, text-fig. 59D, E, J.

1965 Neoglyphioceras cloudi. - King, p. 42.

1971 Lyrogoniatites newsomi cloudi. - Furnish and Saunders, pl. 2, fig. 5.

2009b Pachylyroceras cloudi. - Kullmann, p. 65, text-fig. $38.5 \mathrm{a}-\mathrm{d}$.

Holotype: Specimen USNM 113011; illustrated by Miller and Youngquist (1948, pl. 94, figs. 1-3).

Type locality and horizon: $3.5 \mathrm{~km}$ south of San Saba, Texas (Chappel Hill locality); lower portion of Barnett Shale, probably Choctawites cumminsi Biozone.

Diagnosis: Species of Pachylyroceras with rounded umbilical shoulder and 23-30 spiral lines.

Material: A total of 22 specimens; 21 specimens from sample 00TXCU-27 (NPL 68540 through NPL 68560) and 1 specimen from NMC 1/03-14 (UTSA 07023). All of the specimens are from the same starved interval and are nearly all black to dark brown coloured phosphatic steinkerns with rare phosphatized shell remains preserved. All show various states of corrosion and dissolution.

Description: The earliest whorls are not preserved in the material, but in specimen NPL 68540 the conch has achieved a discoidal shape with moderately depressed whorls and a medium width umbilicus $(\mathrm{ww} / \mathrm{dm}=0.54 ; \mathrm{uw} / \mathrm{dm}=$ 0.30 ) by $21 \mathrm{~mm}$ diameter (Fig. 15a). The whorl cross section is slightly depressed ( $\mathrm{ww} / \mathrm{wh}=1.41$ ) with a broadly rounded umbilical shoulder and broadly rounded ventral region. The internal mould shows rather prominent constrictions, being rectiradiate at the umbilical margin, and bending rather sharply forward at the ventrolateral shoulder forming a pronounced ventral salient and a shallow ventral sinus. Longitudinal lirae are relatively coarse; 28 can be counted from umbilical shoulder to umbilical shoulder.

The suture line of specimen NPL 68542 (phragmocone whorl width of $13.2 \mathrm{~mm}$, whorl height of $8.0 \mathrm{~mm}$ ) shows a Vshaped external lobe with sinuous flanks and slightly asymmetric prongs. The median saddle has a height of one-third of the external lobe depth. On the flanks follow a bell-shaped ventrolateral saddle and a symmetric adventive lobe with slightly convex flanks (Fig. 16c).

Discussion: The Sierra Diablo material of Pachylyroceras appears to represent only a single species, with all specimens being very close to each other in ornament and morphology.
They are also close, in their conch width/diameter and umbilical width ratios, to several of the paratypes in the type lot from San Saba. As has been pointed out by Gordon (1965), the holotype is atypical for the type material in that it possesses five fewer spiral lines and a much wider umbilicus, rather approaching the morphology of "Neoglyphiceras hyatti Gordon, 1960" than the other types. However, the holotype is the largest specimen in the type lot by about $4 \mathrm{~mm}$, and these differences may be the result of later ontogenetic changes or strong variation rather than of taxonomic value. Unfortunately, because the type lot was collected from ex situ nodules and has no detailed stratigraphic context, it is possible that the type lot is from a different horizon. Occurrence: Ruzhencev and Bogoslovskaya (1971) reported the species from the South Urals, but we consider this assignment erroneous because the conch shape, suture, and ornament of the Uralian forms are fundamentally different from the type of $P$. cloudi. We propose the new name Uralyroceras arquatum (named after the arched course of the constrictions) for the Uralian species (see below). Pachylyroceras cloudi appears to be characteristic of the Choctawites cumminsi Biozone of the eastern USA and equivalent age strata in Nevada and Utah.

\section{Uralyroceras n. gen.}

Type species: Pachylyroceras constrictum Ruzhencev and Bogoslovskaya, 1971.

Genus diagnosis: Representatives of the family Neoglyphioceratidae with subevolute to evolute conch, which becomes more evolute in the adult stage. 20-30 coarse spiral lines, growth lines, and shell constrictions nearly linear or with low ventral projection. Suture line with narrow external lobe, usually with slightly sinuous flanks.

Included species:

angustum: Pachylyroceras angustum Ruzhencev and Bogoslovskaya, 1971, p. 246; South Urals.

consequens: Pachylyroceras consequens Ruzhencev and Bogoslovskaya, 1971, p. 245; South Urals.

constrictum: Pachylyroceras constrictum Ruzhencev and Bogoslovskaya, 1971, p. 247; South Urals.

arquatum: Uralyroceras arquatum new species; South Urals. (new name for Pachylyroceras cloudi in Ruzhencev and Bogoslovskaya, 1971, p. 244).

esini: Pachylyroceras esini Nikolaeva, 1994, p. 83; Darvaz (Tajikistan).

? hyatti: Neoglyphioceras hyatti Gordon, 1965, p. 139; Texas.

Discussion: Uralyroceras differs from Pachylyroceras in the course of the shell constrictions, which extend with a low and wide projection across the venter in the new genus but with a ventral sinus as in Pachylyroceras. 
Table 9. Conch dimensions and ratios for Pachylyroceras cloudi (Miller and Youngquist, 1948) from the type area and the Sierra Diablo.

\begin{tabular}{lrrrrrrrrrr}
\hline Specimen & dm & ww & wh & uw & ah & ww / dm & ww / wh & uw / dm & WER & IZR \\
\hline Holotype & 30.4 & 16.8 & 10.1 & 12.7 & 5.8 & 0.55 & 1.66 & 0.42 & 1.53 & 0.43 \\
NPL 68541 & 21.7 & 10.7 & 8.2 & 6.8 & - & 0.49 & 1.30 & 0.31 & - & - \\
NPL 68540 & 21.2 & 11.4 & 8.1 & 6.4 & 4.3 & 0.54 & 1.41 & 0.30 & 1.57 & 0.47 \\
UTSA 07023 & 19.9 & 10.3 & 6.0 & 6.0 & 4.0 & 0.52 & 1.72 & 0.30 & 1.57 & 0.33 \\
NPL 68543 & 14.0 & 7.9 & 5.0 & 4.6 & 2.5 & 0.56 & 1.58 & 0.33 & 1.48 & 0.50 \\
\hline
\end{tabular}

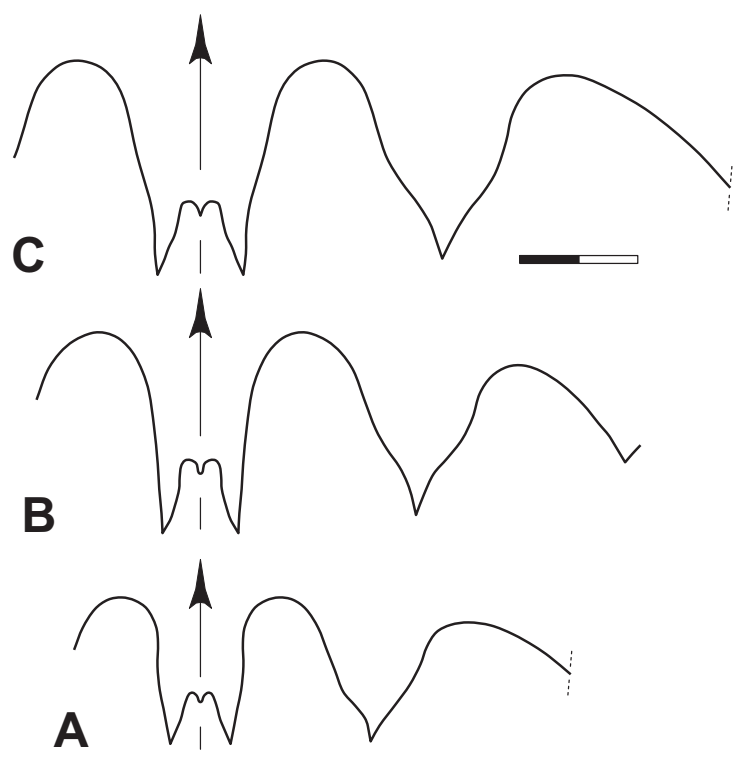

Figure 16. Suture lines of representatives of Pachylyroceras from localities in Utah, Nevada, and Texas; all $\times 6.0$. (a) Pachylyroceras utahensis (Miller et al., 1952), specimen NPL 68561 from Skunk Spring, Utah, at $11.6 \mathrm{~mm}$ diameter, $8.3 \mathrm{mmww}$, $5.6 \mathrm{~mm}$ wh. (b) Pachylyroceras utahensis (Miller et al., 1952), specimen MB.C.25472 from Hamilton Canyon, Nevada, at $9.3 \mathrm{~mm}$ ww, $6.1 \mathrm{~mm}$ wh. (c) Pachylyroceras cloudi (Miller and Youngquist, 1948), specimen NPL 68542 from bed 25 of the Figure 2 Ranch, Texas, at $13.2 \mathrm{~mm} \mathrm{ww}, 8.0 \mathrm{~mm}$ wh.

\section{Conclusions}

The Mississippian to Pennsylvanian section in the Sierra Diablo is remarkable in that it preserves in one place a Late Viséan through Moscovian ammonoid record that rivals any other known from North America. The strata were deposited on the north side of the Marathon Foredeep and represent deeper water offshore facies rich in pelagic fauna. For the pre-Pennsylvanian portion of this record, three-dimensional material appears to be limited to facies representing relative low stands in sea level (e.g. Titus, 1999), indicating that sea level was especially low during the Viséan Goniatites eganensis, Goniatites multiliratus, and Choctawites cumminsi biozones, as well as the succeeding Serpukhovian Tumulites varians Biozone. Key events for correlation of North Amer- ican and western European ammonoid faunas appear to be the first appearance of Neoglyphioceras and advanced Sulcogirtyoceras bearing angular juvenile whorl edges (e.g. S. burhennei). The Sierra Diablo ammonoid assemblages are low diversity in both the Goniatites and Choctawites intervals, with only Goniatites and Girtyoceras known from the former and Choctawites and Pachylyroceras from the latter. However, it must be pointed out that the sample sizes are relatively small. The collections described herein along with historic collections made over 50 years ago will be the only ones available for the foreseeable future even though more field work is required at this scientifically significant locality to establish the exact stratigraphic relationships of the Serpukhovian and Bashkirian ammonoid assemblages.

The new genus Choctawites, which dominates the youngest Sierra Diablo Viséan assemblage, appears to be largely confined to the Appalachian-Ouachita-Marathon foreland basin system and is only rarely found in timeequivalent strata (Chainman Shale) of Nevada and Utah.

Acknowledgements. We thank Ron Stasny for access to the Figure 2 Ranch and permission to collect the material described in this article. Thanks to Evelin Stenzel (Berlin) for preparation work as well as Wolfgang Gerber (Tübingen) and Jana Suchocka (Berlin) for taking the photographs. This contribution is based in part on work supported by the Texas Advanced Research Program under grant no. 003658-0906r-1999. D. Korn acknowledges financial support by the German Research Foundation (Deutsche Forschungsgemeinschaft; project KO1829/6-1). We acknowledge the reviews by Christian Klug (Zürich) and Nick Riley (Nottingham).

Edited by: F. Witzmann

Reviewed by: N. J. Riley and C. Klug

\section{References}

Branson, C. C.: Large Specimen of Goniatites, Oklahoma Geology Notes, 24, 287-288, 1964.

Branson, C. C., Elias, M. K., and Amsden, T. W.: Type of Goniatites choctawensis, Oklahoma Geology Notes, 19, 157-164, 1959.

Cloud, P. and Barnes, V. E.: The Ellenburger group of central Texas, Texas University Bureau of Economic Geology Publications, 4621, 1-473, 1948. 
Collinson, C.: Mississippian prolecanitid goniatites from Illinois and adjacent areas, J. Paleontol., 29, 433-438, 1955.

de Haan, G.: Monographia Ammoniteorum et Goniatiteorum, Hazenberg, Lugduni Batavorum, 168 pp., 1825.

Drahovzal, J. A.: Mississippian Ammonoids from Alabama, Kentucky Geological Survey Special Publication, 10, 62-64, 2009.

Drahovzal, J. A. and Quinn, J. H.: A new Goniatites species from the Chesterian of Arkansas, J. Paleontol., 46, 581-590, 1972.

Elias, M. K.: Upper Mississippian and lower Pennsylvanian Formations of South-Central Oklahoma, Petroleum Geology of Southern Oklahoma, American Association of Petroleum Geologists, 56-134, 1956.

Furnish, W. M. and Saunders, W. B.: Ammonoids from the Middle Chester Beech Creek Limestone, St. Clair County., University of Kansas, Paleontological Contributions, 51, 1-14, 1971.

Girty, G. H.: The fauna of the Caney Shale of Oklahoma, Bulletin of the U.S. Geological Survey, 377, 1-106, 1909.

Girty, G. H.: The fauna of the Moorefield Shale of Arkansas, Bulletin of the U.S. Geological Survey, 439, 1-148, 1911.

Gordon, M. J.: Some American Midcontinent Carboniferous Cephalopods, J. Paleontol., 34, 133-151, 1960.

Gordon, M. J.: Species of Goniatites in the Caney Shale of Oklahoma, J. Paleontol., 36, 355-357, 1962.

Gordon, M. J.: Carboniferous Cephalopods of Arkansas, Professional Papers, U.S. Geological Survey, 460, 1-322, 1965.

Gordon, M. J.: Goniatites americanus n. sp., a late Meramec (Mississippian) index fossil, Geological Survey Res., 1971, C39-C43, 1971.

Hammer, Ø., Harper, D., and Ryan, P.: PAST-PAlaeontological STatistics, ver. 1.89, University of Oslo, Oslo, 2009.

Harrell, J. E.: Formal recognition of the Folks Member of the Barnett Formation in the western Deleware Basin, Figure 2 Ranch, Culberson County, West Texas Geological Society Bulletin, 46, 8-21, 2007.

Hyatt, A.: Genera of fossil cephalopods, Proceedings of the Boston Society of Natural History, 253-338, 1883-1884.

Hyatt, A.: Carboniferous cephalopods, second paper, 4th Annual Report of the Geological Survey of Texas, 327-356, 379-474, 1893.

King, P. B.: Geology of the Sierra Diablo Region Texas, Professional Papers, U.S. Geological Survey, 480, 1-185, 1965.

Klug, C., Döring, S., Korn, D., and Ebbighausen, V.: The Visean sedimentary succession at the Gara el Itima (Anti-Atlas, Morocco) and its ammonoid faunas, Fossil Record, 9, 3-60, 2006.

Korn, D.: Die Goniatiten des Kulmplattenkalkes (Cephalopoda, Ammonoidea; Unterkarbon; Rheinisches Schiefergebirge), Geologie und Paläontologie in Westfalen, 11, 1-293, 1988.

Korn, D.: Evolution of the Goniatitaceae and Visean-Namurian biogeography, Acta Palaeontol. Pol., 42, 177-199, 1997a.

Korn, D.: The Palaeozoic ammonoids of the South Portuguese Zone, Memorias do Instituto geologico e Mineiro, 33, 1-131, $1997 b$.

Korn, D.: A key for the description of Palaeozoic ammonoids, Foss. Rec., 13, 5-12, doi:10.5194/fr-13-5-2010, 2010.

Korn, D. and Ebbighausen, V.: The Early Carboniferous (Mississippian) ammonoids from the Chebket el Hamra (Jerada Basin, Morocco), Foss. Rec., 11, 83-156, doi:10.5194/fr-11-83-2008, 2008.
Korn, D. and Horn, K.: The Late Viséan (Early Carboniferous) goniatite stratigraphy in the South Portuguese Zone, a comparison with the Rhenish Massif, Newsletters on Stratigraphy, 35, 97113, 1997.

Korn, D. and Kaufmann, B.: A high-resolution relative time scale for the Viséan Stage (Carboniferous) of the Kulm Basin (Rhenish Mountains, Germany), Geol. J., 44, 306-321, 2009.

Korn, D. and Klug, C.: Conch form analysis, variability, morphological disparity, and mode of life of the Frasnian (Late Devonian) ammonoid Manticoceras from Coumiac (Montagne Noire, France), in: Cephalopods Present and Past: New Insights and Fresh Perspectives, edited by: Landman, N. H., Davis, R. A., and Mapes, R. H., Springer, New York, 57-85, 2007.

Korn, D. and Titus, A. L.: Goniatites Zone (middle Mississippian) ammonoids of the Antler Foreland Basin (Nevada, Utah), Bull. Geosci., 86, 107-196, doi:10.3140/bull.geosci.1242, 2011.

Korn, D., Klug, C., and Mapes, R. H.: Visean and Early Namurian Ammonoids from the Tafilalt (Eastern Anti-Atlas, Morocco), Abhandlungen der Geologischen Bundesanstalt, 54, 345-375, 1999.

Korn, D., Ebbighausen, V., Bockwinkel, J., and Klug, C.: The Amode sutural ontogeny in prolecanitid ammonoids, Palaeontology, 46, 1123-1132, 2003.

Korn, D., Klug, C., and Mapes, R. H.: Cuboid Carboniferous ammonoids, Mitteilungen aus dem Geologisch-Paläontologischen Institut der Universität Hamburg, 88, 79-8, 2004.

Korn, D., Bockwinkel, J., and Ebbighausen, V.: Tournaisian and Visean ammonoid stratigraphy in North Africa, Neues Jahrbuch für Geologie und Paläontologie, Abhandlungen, 243, 127-148, 2007.

Korn, D., Bockwinkel, J., and Ebbighausen, V.: The ammonoids from the Argiles de Teguentour of Oued Temertasset (early Late Tournaisian; Mouydir, Algeria), Foss. Rec., 13, 35-152, doi:10.5194/fr-13-35-2010, 2010.

Kullmann, J.: Goniatitoidea, in: Treatise on Invertebrate Paleontology. Part L. Mollusca 4 Revised. Volume 2: Carboniferous and Permian Ammonoidea (Goniatitida and Prolecanitida), edited by: Seldon, P. A., The University of Kansas Paleontological Institute, Lawrence, Kansas, 52-60, 2009a.

Kullmann, J.: Agathiceratoidea, in: Treatise on Invertebrate Paleontology. Part L. Mollusca 4 Revised. Volume 2: Carboniferous and Permian Ammonoidea (Goniatitida and Prolecanitida), edited by: Seldon, P. A., The University of Kansas Paleontological Institute, Lawrence, Kansas, 60-62, 2009b.

Kullmann, J. and Pitz, T.: Dombarites (Goniatitida, Cephal.) aus dem Ober-Vise des Rheinischen Schiefergebirges, Neues Jahrbuch für Geologie und Paläontologie, Abhandlungen, 159, 297-323, 1980.

Kullmann, J., Wagner, R. H., and Winkler Prins, C.: Significance for international correlation of the Perapertú Formation in northern Palencia, Cantabrian Mountains. Tectonic/stratigraphic context and description of Mississippian and Upper Bashkirian goniatites, Revista Española de Paleontología, 22, 127-145, 2007.

Kusina, L. F.: Viseyskiy kompleks ammonoidei, Paleontologicheskiy Zhurnal, 1987, 52-61, 1987.

Kusina, L. F. and Yatskov, S. V.: Nizhne- i srednekamennougol'nye ammonoidei Novoi Zemli., Trudy Paleontologicheskogo Instituta Rossiyskaya Akademiya Nauk, 275, 1-144, 1999. 
Leonova, T. B.: Permian Ammonoids: Classification and Phylogeny, Paleontol. J, Supplement, 36, 1-114, 2002.

Leonova, T. B.: Permian ammonoids: Biostratigraphic, biogeographical, and ecological analysis, Paleontol. J., 45, 1206-1312, 2011.

Librovitch, L. S.: O nekotorykh novykh gruppakh goniatitov iz kamennougolnykh otlozheniy SSSR, Ezhegodnik Vsesoyuznogo Paleontologicheskogo Obshchestva, 16, 246-273, 1957.

Malinky, J. M. and Mapes, R. H.: A new ferganoceratin ammonoid from the Mississippian (Lower Chesterian) of Arkansas, J. Paleontol., 56, 308-314, 1982.

Martin, W.: Petrificata Derbiensia: or, figures and descriptions of petrifactions collected in Derbyshire. Vol. 1, Lyon, Wigan, IX+II+II +28 pp., 1809.

McCaleb, J. A., Quinn, J. H., and Furnish, W. M.: The ammonoid family Girtyoceratidae in the Southern Midcontinent, Circular of the Oklahoma Geological Survey, 67, 1-41, 1964.

Miller, A. K. and Downs, R. H.: Additional ammonoids from the Mississippian Barnet Formation of Texas, J. Paleontol., 24, 575576, 1950.

Miller, A. K. and Furnish, W. M.: Studies on Carboniferous ammonoids: parts 1-4, J. Paleontol., 14, 356-377, 1940a.

Miller, A. K. and Furnish, W. M.: Studies of Carboniferous ammonoids: parts 5-7, J. Paleontol., 14, 521-543, 1940 b.

Miller, A. K. and Furnish, W. M.: Middle Pennsylvanian Schistoceratidae (Ammonoidea), J. Paleontol., 32, 253-268, 1958.

Miller, A. K. and Youngquist, W.: The cephalopod fauna of the Mississippian Barnett Formation of Central Texas, J. Paleontol., 22, 649-671, 1948.

Miller, A. K., Downs, R. H., and Youngquist, W.: Some Mississippian cephalopods from central and western United States, J. Paleontol., 23, 600-612, 1949.

Miller, A. K., Youngquist, W., and Nielsen, M. L.: Mississippian cephalopods from Western Utah, J. Paleontol., 26, 148-161, 1952.

Miller, S. A.: North American Geology and Palaeontology for the use of amateurs, students and scientists, 1-664, 1889.

Miller, S. A. and Faber, C.: Description of some Subcarboniferous and Carboniferous Cephalopoda, Journal of the Cincinati Society of Natural History, 14, 164-168, 1892.

Miller, S. A. and Gurley, W. F. E.: New species of Palaeozoic invertebrates from Illinois and other states, Bulletin of the Illinois State Museum of Natural History, 11, 1-50, 1896.

Nikolaeva, S. V. and Konovalova, V. A.: Genus Lusitanoceras and its role in the Evolution of Goniatitaceans, Paleontol. J., Supplement, 39, 558-572, 2005.

Pereira De Sousa, F. L.: Sur un nouveau genre de Goniatite: Lusitanoceras, Bulletin de la Societe Geologique de France, 423, 304, 1923.

Plummer, F. B.: The Carboniferous rocks of the Llano region of Central Texas, Publications of the University Texas, 4329, 1-170, 1950.

Plummer, F. B. and Scott, G.: Upper Paleozoic ammonites in Texas, The geology of Texas, vol. pt., Bull. Texas. Univ., 313701, 1516, 1937.

Ramsbottom, W. H. C. and Saunders, W. B.: Evolution and evolutionary biostratigraphy of Carboniferous ammonoids, J. Paleontol., 59, 123-139, 1985.
Rauser-Tschernoussowa, D. M.: O nekotorykh kamennougolnykh ammonitakh Fergany, Izvestiya Assotsiatsii issledovaniya institutov pri 1 Moskosvskovo universiteta, fiziko-matematicheskiy fakul'tet, 1, 164-178, 1928.

Ruzhencev, V. E.: Filogeneticheskaya sistema paleozoiskikh ammonoidei., Byulleten' Moskovskogo obshchestva ispytatelei prirody, otdelenie geologii, 32, 49-64, 1957.

Ruzhencev, V. E. and Bogoslovskaya, M. F.: Reviziya nadsemeystva Goniatitaceae, Paleontologicheskiy Zhurnal, 1970, 52-65, 1970.

Ruzhencev, V. E. and Bogoslovskaya, M. F.: Namyurskiy etap v evolyutsii ammonodey. Rannenamyurskiye ammonoidei., Trudy Paleontologicheskogo Instituta Akademiya Nauk SSSR, 133, 1382, 1971.

Ruzhencev, V. E. and Bogoslovskaya, M. F.: Namyurskiy etap v evolyutsii ammonodey. Pozdnenamyurskiye ammonoidei, Trudy Paleontologicheskogo Instituta Akademiya Nauk SSSR, 167, 1336, 1978.

Saunders, W. B., Manger, W. L., and Gordon, M. J.: Upper Mississippian and lower and middle Pennsylvanian ammonoid biostratygraphy of Northern Arkansas, Oklahoma Geolological Survey Guidebook, 18, 117-137, 1977.

Shumard, B. F.: Descriptions of new Paleozoic fossils, Transactions of the St. Louis Academy of Science, 2, 108-113, 1863.

Smith, J. P.: The Carboniferous Ammonoids of America, Monographs of the U.S. Geological Survey, 42, 1-211, 1903.

Sowerby, J.: Mineral Conchology of Great Britain, volume I., B. Meredith, London, 234 pp., 1812-1814.

Titus, A. L.: Ammonoid biostratigraphy of the Barnett Shale (late Mississippian), Texas, USA, in: Fossil cephalopods: Recent advances in their study, edited by: Rozanov, A. Yu. and Shevyrev, A. A., Paleontologicheskogo Instituta Rossiyskaya Akademiya Nauk, 155-168, 1999.

Titus, A. L. and Riley, N. J.: Recognition and correlation of eustatic flooding events in the late Visean of Utah (SW USA) and Britain (NW Europe), Newsletter on Carboniferous Stratigraphy, 15, 1922, 1997.

Wagner-Gentis, C. H. T.: Goniatites from the Viséan-Namurian junction beds in Palencia, NW Spain, Scripta Geologica, 55, 143, 1980.

Webster, G., Brenckle, P., Gordon Jr., M., Lane, H., Langenheim Jr., R., Sanderson, G., and Tidwell, W.: The MississippianPennsylvanian boundary in the eastern Great Basin, Neuvieme Congrès International de Stratigraphie et de Géologie du Carbonifère, Comptes Rendu, 406-418, 1984.

Wedekind, R.: Die Genera der Palaeoammonoidea (Goniatiten), Mit Ausschluß der Mimoceratidae, Glyphioceratidae und Prolecanitidae, Palaeontographica, 62, 85-184, 1918.

Work, D. M. and Mason, C. E.: The Mississippian Ammonoid Succession in the Central Appalachian Basin, Eastern Kentucky, in: Carboniferous Geology and Biostratigraphy of the Appalachian Basin, Kentucky Geological Survey, Special Publication, 10, edited by: Greb, S. F. and Chesnut, D. R. J., University of Kentucky, Lexington, 65-70, 2009a.

Work, D. M. and Mason, C. E.: The Mississippian Ammonoid Succession in the Central Appalachian Basin, Eastern Kentucky, Geological Survey Special Publication, 10, 65-70, 2009 b.

Youngquist, W.: The cephalopod fauna of the White Pine shale of Nevada, J. Paleontol., 23, 276-305, 1949. 